\title{
1 A new role for pond management in farmland bird conservation
}

2

3 Davies $\mathrm{SR}^{1 *}$, Sayer $\mathrm{CD}^{1}$, Greaves $\mathrm{H}^{1}$, Siriwardena $\mathrm{GM}^{2}$, Axmacher JC¹.

4

5 1. Pond Restoration Research Group, Environmental Change Research Centre, Department of

6 Geography, University College London, London, UK

7 2. British Trust for Ornithology, The Nunnery, Thetford, Norfolk IP24 2PU, UK

8 Corresponding author, Email: sarah.r.davies90@gmail.com

ABSTRACT

1. Biodiversity declines in agricultural landscapes represent a major conservation challenge. In the UK, some agricultural landscapes contain high pond densities, but many farmland ponds have become terrestrialised since the 1960s, with input of organic material resulting in a decrease in the size and depth of ponds that eventually transform into wet woodland habitats. Pond management, including removal of overhanging scrub and sediment, has proven highly effective in enhancing freshwater biodiversity. However, the implications of this management for farmland bird assemblages are unknown.

2. Bird surveys were undertaken at recently managed, open, macrophyte-dominated and at highly terrestrialised, macrophyte-free ponds in the intensively cultivated farmland of North Norfolk, UK. The diversity, abundance and composition of bird assemblages visiting these ponds were compared to determine responses to pond management by tree and mud removal.

3. Avian species richness, abundance and bird-visit frequencies were all higher at open farmland ponds. The observed patterns of bird occurrence were best explained by management-induced reductions in tree shading that resulted in aquatic macrophyte-dominance likely associated with high emergent invertebrate prey abundance. Moreover, we predict that open-canopy ponds offer greater habitat heterogeneity than overgrown ponds, allowing diversified bird use. Overgrown, terrestrialised ponds were preferred by some woodland bird species. Gamma diversity across the entire pondscape exceeded all individual pond alpha diversity measures by an order of magnitude, suggesting distinct 
variation in the bird assemblages visiting farmland ponds during different successional stages.

4. Pond management that generates a mosaic of pond successional stages, including open-canopy, macrophyte-dominated ponds, could help to address the long-term decline of farmland birds. We strongly advocate increased agro-ecological research in this field, combined with greater emphasis on ponds and pond management options in agri-environment schemes.

Keywords: Agri-environment schemes, agro-ecosystems, avian diversity, biodiversity decline, farmland pondscapes, habitat heterogeneity.

\section{INTRODUCTION}

Landscapes in many parts of the world are dominated by farmland (Foley et al. 2005, Scherr \& McNeely 2008). Accordingly, agricultural landscapes have attracted substantial attention from the conservation research community. Historically, agricultural landscapes represented a highly dynamic habitat mosaic characterized by substantial spatio-temporal variations in environmental conditions (Chamberlain et al. 2000, Bennett et al. 2006). The resulting heterogeneity, at both local and regional scales, has been recognised as a primary factor underpinning historical agricultural landscape biodiversity (Benton et al. 2003, Tscharntke et al. 2005, Fahrig et al. 2011). Accordingly, increases in agricultural intensification and associated agricultural habitat homogenization from the 1940s onwards, in combination with encroachments on remaining non-agricultural habitats, have resulted in a marked biodiversity reduction across the European countryside (Fuller 2000, Ford et al. 2001, Robinson \& Sutherland 2002, Burel et al. 2004, Stoate et al. 2009, van Zanten et al. 2014).

Nearly 120 European bird species of conservation concern use lowland farmland habitats as either breeding or wintering habitat. A number of conservation priority species like the song thrush Turdus merula, yellowhammer Emberiza citrinella and reed bunting Emberiza schoeniclus, additionally rely on non-crop structures such as meadows, scrubland, woodlands, hedgerows and individual trees in agricultural landscapes as foraging, breeding and nesting sites (Whittingham et al. 2009, Marja \& Herzon 2012). Other birds such as skylark Alauda arvensis and grey partridge Perdix perdix are strongly affected by the quality of cropped habitats and marginal habitats such as fallows and rough 
ground. Some $83 \%$ of European farmland bird species have undergone declines in abundance between 1970 and 1990 as a result of agricultural intensification. For $86 \%$ of these species, reductions were significant, and these trends have continued into the $21^{\text {st }}$ century (Fuller et al. 1995, Donald et al. 2001, Barker 2004, Holland 2004, Butler et al. 2007, Baillie et al. 2014). Threats identified as affecting conservation priority bird species include the loss of old hedgerows, permanent pasture and scrub on farmland, changing sowing regimes, loss of variation in grassland swards, declines in abundance and diversity of insect prey, and reductions in seed resources linked to landuse changes and pesticide use (Chamberlain et al. 2000, Hinsley \& Bellamy 2000, Perkins et al. 2000, Donald et al. 2001, Benton et al. 2002, Barker 2004, Holland 2004).

While a range of approaches to enhance the farmed environment for wildlife have been taken in the UK and across Western Europe, many bird species populations have failed to recover (Donald et al. 2006). Declining UK Biodiversity Action Plan (BAP) species (JNCC 2007) include skylark, starling Sturnus vulgaris, grey partridge and yellow wagtail Motacilla flava (Eaton et al. 2013). Aerial insectivorous birds associated with agricultural environments, such as swift Apus apus and house martin Delichon urbicum, have also shown steep population declines across industrialised European countries (Benton et al. 2002, Rioux Paquette et al. 2014). With farmland bird declines surpassing those in all other environments, serious concerns amongst both the scientific community and the general public have been raised. Currently, the main approach for counteracting farmland bird declines in Europe is the widespread adoption of agri-environment schemes (AES), such as the English Countryside Stewardship Schemes, but these have afforded limited success thus far for agricultural biodiversity (Kleijn et al. 2006, 2011, Baker et al. 2012).

A number of studies have concluded that agricultural management approaches that increase the heterogeneity of the agricultural mosaic will enhance overall species richness across many taxonomic groups at the landscape scale, while simultaneously improving ecosystem services and minimising agricultural yield losses (Pino et al. 2000, Atauri and de Lucio 2001, Weibull et al. 2003, Doxa et al. 2010, Sabatier et al. 2014). Soininen et al. (2015) stressed the importance of aquatic habitats for conservation, not only for aquatic organisms, but also for terrestrial species due to the contribution of potential cross-system subsidies from freshwater ecosystems which enhance terrestrial ecosystem 
functioning. Small wetlands, and especially ponds, may therefore play a crucial role in improving both aquatic and terrestrial biodiversity at the landscape scale, while also serving to increase habitat heterogeneity (Williams et al. 2004, Davies et al. 2008, Céréghino et al. 2008, Lemmens et al. 2013).

Ponds are of particular significance to biodiversity conservation in agricultural landscapes, forming habitat islands for a wide range of aquatic and semi-aquatic organisms in an otherwise species-poor environment (Declerck et al. 2006, Davies et al. 2008, Ruggiero et al. 2008). Unfortunately, many farmland ponds are threatened by in-filling (via land reclamation) and pollution due to agricultural intensification (Wood et al. 2003, Biggs et al. 2005, Céréghino et al. 2014). In addition, as a consequence of the general cessation of traditional pond management practices over the last 30-40 years (Sayer et al. 2013), a high proportion of UK farmland ponds have undergone terrestrialization, with the accumulation of litter and other organic material over time resulting in a decrease in pond size and depth. Many ponds also become increasingly encroached by woody vegetation and eventually transform into wet woodland, while in the absence of shrub and tree encroachment, pond succession can lead towards fen-swamp habitats. Indeed, in many areas, overgrown, tree-shaded ponds are overwhelmingly dominant, resulting in sharp declines in landscape-scale aquatic diversity (Sayer et al. 2011; 2012). Approaches to combat widespread terrestrialisation include the creation of new ponds through initiatives such as the UK Million Ponds Project (Williams et al. 2010). As an alternative, existing, overgrown farmland ponds can be managed and restored via the removal of encroaching trees, scrub and accumulated pond sediment. The latter process effectively 'resets' succession thereby increasing the quality and quantity of open water habitats. Sayer et al. (2012) determined that macrophyte and invertebrate diversity was greatly enhanced in a managed pondscape comprising a mosaic of ponds at different successional stages set in an intensively managed agricultural landscape. Diversity patterns were strongly driven by degree of shading, with agricultural ponds previously deficient in macrophytes becoming macrophyte-dominated after management, providing habitat for a diverse array of species. Currently, both the UK Countryside Stewardship Scheme (CS) and Glastir Land Management Scheme for Wales offer options for maintaining and buffering ponds on farmland (Welsh Government 2015, Natural England 2015). Nonetheless, pond management itself is only included as a higher tier option within CS, and overall pond management remains relatively poorly promoted within UK AES. 
117 While the influence of pond management on aquatic species assemblages is now established (Gee et

118 al. 1997, Sayer et al. 2012), the links between pond management and the terrestrial environment

119 have been comparatively neglected. Farmland ponds generally harbour substantial numbers of 120 aquatic macroinvertebrates whose adult aerial stages are known to constitute an important food 121 resource for nesting and fledging birds (Newton 1998, Baxter et al. 2005, Richardson et al. 2010, 122 Schummer et al. 2012, Stenroth et al. 2015), and wintering waterbirds (Matuszak et al. 2014). In 123 addition, mixed grassland margins around open ponds may increase the availability and diversity of broad-leaved plants and seeds utilised as a food resource by granivores (McCracken \& Tallowin 2004); we believe that these open pond margins are of high importance to birds.

We examine the value of a set of open, managed ponds and overgrown, non-managed ponds for bird communities in the intensively farmed agricultural landscape of North Norfolk, Eastern England. We predict that the benefits of pond management will strongly affect terrestrial organisms, as exemplified by the farmland bird community. The term 'farmland bird' in this context is used to encompass any species encountered within the agricultural landscape. This includes waterfowl, reed-nesting species, ground-nesting species and birds of prey, as well as open-country, woodland, scrubland and grassland bird species. We hypothesize that managed, macrophyte-dominated ponds attract a greater diversity of bird species than unmanaged, overgrown ponds, since they not only provide a higher diversity and abundance of emerging invertebrates and greater seed provision subsidy, but also increase habitat heterogeneity in the farmland landscape through provision of vegetated water and wet reed/sedge-dominated margins. We furthermore hypothesize that overgrown ponds primarily act as woodland habitat islands, occupied predominantly by woodland bird species. We finally hypothesize that bird assemblages use open and overgrown ponds for different activities in accordance with variations in habitat preference and food availability.

\section{METHODS}

\subsection{Study Site} the villages of Melton Constable, Stody and Briston in North Norfolk (Fig.1). Most ponds in this region 
were created either for marl extraction or livestock watering between the $17^{\text {th }}$ and $19^{\text {th }}$ centuries (Prince 1964). Of the $\sim 60$ small ponds ( $<20$ in diameter) in the $\sim 10 \mathrm{~km}^{2}$ study area, a total of 22 ponds on privately owned farmland were selected for this study, thus allowing us to cover $\sim 36.6 \%$ of the pondscape. Selected ponds included 11 open canopy ponds with generally high submerged and fringing aquatic macrophyte cover (Fig.2a, b) and 11 closed-canopy, overgrown ponds dominated by living and fallen trees of Prunus spinosa, Salix spp. and Alnus glutinosa, where aquatic plants were largely absent (Fig.2c). All the ponds located in arable fields were surrounded by grassland buffers of at least $7 \mathrm{~m}$ width installed as part of Higher Level Stewardship (HLS) agreements.

The open canopy ponds were located at Manor Farm, Briston. Since the 1960s, most ponds at Manor Farm have been subject to a pond management programme comprising periodic scrub and pond sediment removal undertaken at two to four ponds each year with the aim of arresting terrestrialisation. This approach has created a mosaic of ponds varying in terms of degree of scrub encroachment and macrophyte cover. The resulting managed pondscape at Manor Farm is host to species-rich aquatic communities that include at least 16 breeding dragonfly species and the threatened Great Crested Newt, Triturus cristatus, which breeds in around 28 of the 40 ponds (Sayer et al. 2012, Sayer et al. 2013). Moreover, the pondscape supports species-rich $(n=24)$ communities of aquatic plants with frequent dominance of Potamogeton natans in open water and fringing emergent vegetation typically including Sparganium erectum, Typha latifolia and Epilobium hirsutum.

\subsection{Field surveys}

All ponds included in the study were assigned an individual code depending on their location (Manor Farm ponds - W, Stody ponds - S, Daniel's Farm ponds - D, Melton Constable ponds - M) (Fig.1). Bird surveys were carried out at 11 managed, open ponds at Manor Farm, (W1-W37) and 11 late succession, overgrown ponds on surrounding farmland in the Stody/Hunworth/Melton Constable area (M1, D6, S4-S15). Most ponds formed isolated habitat "islands" on arable cropland or within cattle pastures where livestock were present at the time of the study (W1, W34, W37, S15). A number of ponds were along field boundaries and connected to hedgerow corridors (W34, W37, S4, S13, S15). On two occasions, ponds were situated within fields adjacent to patches of woodland (W1, M1). Three 
connected open-canopy ponds on Manor Farm were included in this study as a single pond complex, and thus are treated as one pond, termed the W22, 23, 24 cluster.

In June 2014, each of the 22 ponds was visited on five separate occasions, resulting in a total of 110 pond visits. Surveys were conducted during early mornings (5-10 am) and in good weather conditions, to avoid bias from lowered bird activity during periods of wet weather. Visit order was also randomized to avoid survey bias relating to time of day. During each individual pond visit, all birds encountered by sight, song or call were recorded over a set period of 20 minutes. Additional information recorded included the location of each bird individual on or around the pond (e.g. open water, surrounding vegetation, grassland buffer, stands of aquatic macrophytes) and bird behavioural activities: foraging, travelling, sheltering, vocal display, territorial behaviour, group behaviour and parental behaviour (including the provisioning of chicks). The activities and location of bird species for both pond types were subsequently compared by independent samples t-tests to determine differences in behaviour and habitat choice at open and overgrown ponds. Surveys were conducted at a location maximizing the visibility of the open pond surface area and the surrounding vegetation while minimizing disturbance (Bibby et al. 1992). Active searches were also carried out around the circumference of each pond so that particularly large or obstructed sites could be viewed from different angles. All individual birds observed in or around the pond (up to $10 \mathrm{~m}$ away), including at directly adjacent trees, shrub and surrounding grassland buffer strips were recorded. Birds flying above the pond were also included, provided that they showed aerial feeding behaviour or flew low over the open water/tree canopy. Where possible, all encountered birds were identified to species level and subsequently grouped into 'guilds' based on avian family, diet (granivorous, insectivorous) and habitat preference (open country, scrubland, woodland, wetland, ground-nesting, reed nesting). In some instances, where sightings were very brief, distinguishing similar, closely-related species resulted in a high risk of misidentification. Species affected were the warbler genera Phylloscopus (chiffchaff/willow warbler), Sylvia spp. (garden warbler/blackcap), Anas spp. (mallard/gadwall) and Motacilla spp. (grey/yellow wagtail). Due to habitat preferences and species abundances, it was assumed that the respective unidentified female wagtails were yellow wagtails and female ducks were mallards, whereas in the other two cases, we combined all counts for the sets of two species and treated them as "super-species" in the statistical analysis. 
204 Environmental data for each pond, including pond circumference, \% pond surface shaded by trees, \% pond circumference covered by trees, \% coverage of pond surface by emergent (fringing) macrophytes and \% coverage by submerged/floating-leaved macrophytes (assessed visually) were collected in 2012 and 2014. All aquatic plants were recorded on the DAFOR scale (Dominant - 5, Abundant - 4, Frequent - 3, Occasional - 2, Rare - 1) as described by Palmer et al. (1992), via visual assessments assisted by collections made using a double-headed rake.

\subsection{Data analysis}

212

Species richness, abundance and Simpson's and Shannon's diversity (Crist et al. 2003) were used to represent $\alpha$-and $\gamma$-diversity, calculated by combining the records of the five individual pond visits. The highest recorded abundance for each bird species from all of the five surveys was used to represent the maximum number of individuals or "abundance" for each pond. Although this approach may still produce an overestimate of total bird abundance, the risk of counting the same individual multiple times is greatly diminished (Toms 2004, BTO 2014). Pond categories were subsequently compared using independent samples t-tests. Bird counts were rarefied using Hurlbert Rarefaction (Hurlbert 1971) to create species accumulation curves for open and overgrown ponds. Correspondence Analysis $(\mathrm{CA})$ was used to examine variation in bird assemblage composition between the ponds and to determine degree of species turnover between ponds (beta diversity) by maximizing the correspondence between species abundance scores and sample scores and measuring how distinct the sampling units were along gradients. Canonical Correspondence Analysis (CCA) was conducted to examine the direct relationships between pond environmental parameters and bird assemblages, again using bird abundance data. In addition, Stepwise Multiple Linear Regression (MLR) was performed to determine the extent to which environmental parameters were linked to overall bird diversity and abundance. Z-transformed environmental data were used in the multivariate analyses. Pearson's correlation analysis showed strong inter-correlations between four of the environmental parameters: submerged/floating and emergent macrophyte cover measures, $\%$ shading and $\%$ of the pond circumference surrounded by trees ( $r \sim 0.7$. Pond circumference was an exception, however, and significantly correlated with percentage shading only $(r=-0.42)$. Using the results of the Pearson's 
correlations a $p$-value threshold for parameter deletion of $p>0.05$ was used, as values larger than this indicated that the effects of the variables upon patterns of avian diversity could not be separated. Subsequently, circumference and submerged/floating macrophyte coverage were chosen for further analysis, while the remaining parameters were omitted from MLR and CCA. It should be noted, however, that a high degree of submerged/floating macrophyte cover can be seen as a powerful proxy for low shading due to the highly negative correlation between these factors (Pearson's Correlation Coefficient, $r=-0.86$ ). Estimates $S 8.2$ was used in the calculation of both $\alpha$-and $y$ diversity (Colwell 2009), while rarefaction curves were calculated using Species Diversity and Richness 3.02 (Pisces Conservation Ltd 2002). CANOCO for Windows 4.5 (ter Braak and Smilauer 2002) was used to generate CA and CCA ordination plots, while t-tests, stepwise MLR, and Pearson's Correlation Coefficient were all calculated in SPSS for Windows 20 (IBM Corp 2011) and R: A Language and Environment for Statistical Computing Version 3.2.2 (R Core Team 2015).

\section{RESULTS}

\subsection{Bird observations}

In total, 58 breeding bird species were observed visiting or holding territories around the 22 farmland ponds (see Appendix A). Some 28 bird species were exclusive to only one pond type, while large proportions of the species encountered at open-canopy and overgrown ponds showed a very clear affinity to one of these pond type, as reflected by higher visit frequencies and abundances. Waterfowl, reed-associated species and open country species (comprising ground-nesting species, insectivorous open country species and a number of granivorous species) were largely confined to open ponds. Nine of the eleven conservation priority UK BAP species that were recorded at the ponds showed a preference for open rather than overgrown ponds. Overall, the open ponds harboured a much higher diversity of bird species and guilds than overgrown ponds. Nonetheless, typical woodland bird species like the great spotted woodpecker Dendrocopos major, treecreeper Certhia familiaris, or nuthatch Sitta europaea, were exclusively encountered at overgrown ponds. Aside from 10 woodland bird species, all species recorded at overgrown ponds were also found at open ponds. 


\subsection{Avian diversity}

262 Two of the largest, open-canopy farmland ponds, W10 and the W22/23/24 cluster, harboured the

263 highest avian diversity (Species Richness, Abundance, Shannon's diversity, Simpson's Diversity);

264 while the bird assemblage recorded at overgrown pond S7 was least diverse. However, Shannon's

265 and Simpsons Diversity did not differ significantly between individual ponds of each type (Table 1).

266 Nonetheless, both the recorded and estimated species richness was significantly higher at open

267 ponds compared to overgrown ponds $(p<0.05$, Table 1$)$. This trend was further supported by

268 rarefaction curves combining samples of the two groups (Fig.3). Gamma diversity across the

269 agricultural pondscape was considerably higher than both the alpha diversity of any one individual

270 pond, and of the combined open and overgrown ponds, indicating important diversity contributions by

271 both pond types (Table 1).

272 In the CA bi-plot, axis 1 explained $15.3 \%$ of species data variance, whereas axis 2 explained a further

$27310.5 \%$. Species turnover between the overgrown ponds was relatively low, as illustrated by the small

274 area of ordination space generally occupied by these sites in the CA (Pond S7 is an outlier due to a

275 record of tawny owl Strix aluco, Fig.4). In contrast, a greater bird species turnover was observed at

276 the open ponds, meaning that these are more heterogeneous in the bird assemblages they support.

277 The bird community structure showed significant variation in relation to the measured environmental

278 gradients in the agricultural pondscape. In the CCA bi-plot (Fig.5), axis 1 was positively related to

279 macrophyte coverage (and thus negatively correlated with shading) and explained $9.99 \%$ of bird

280 species' variance. Axis 2 , which explained an additional $4.43 \%$ of bird species' variance, was strongly

281 associated with pond circumference. Bird species were widely distributed across axis 1 , showing

282 varying preferences for macrophyte coverage and associated shading, but generally the species most

283 prevalent at open ponds, such as aerial insectivores (swift, swallow, house martin), open country

284 species (e.g. whitethroat Sylvia communis, linnet Carduelis cannabina), granivores (e.g. greenfinch

285 Chloris, skylark, house sparrow Passer domesticus), dabbling ducks (mallard Anas platyrhynchos and

286 gadwall Anas strepera) and wetland passerines (reed bunting, reed warbler Acrocephalus scirpaceus

287 and sedge warbler Acrocephalus schoeniclus), preferred lower levels of tree shading (and thus high

288 macrophyte coverage), whereas woodland birds such as robin Erithacus rubecula, nuthatch and

289 treecreeper were associated with increased tree shading (and thus lower macrophyte coverage). 
Birds associated with ponds of intermediate macrophyte coverage and partial shading (e.g. coal tit, long-tailed tit), as well as species equally abundant at both open and overgrown ponds (e.g. chaffinch,

292 yellowhammer, blue tit), clustered towards the centre of the plot.

293

294

MLR indicated that pond circumference and macrophyte coverage were both significant predictors of overall avian species richness $\left(F=11.82\right.$, Adjusted $\left.R^{2}=0.51, p=0.0004\right)$, and abundance $(F=12.32$, Adjusted $\mathrm{R}^{2}=0.52, p=0.0003$ ) (Table 2). While circumference was a significant predictor for Shannon's Diversity (estimate $=0.04, \mathrm{t}$ value $=2.74, p=0.01$ ), this was not true for macrophyte coverage (estimate $=0.35$, $\mathrm{t}$ value $=1.22, p=0.35$ ). In addition, the model failed to explain the patterns in Simpson's Diversity $(p=0.95)$.

\subsection{Pond use by farmland birds}

In addition to vegetated open water, the open agricultural ponds afforded a variety of associated habitats that were utilised by birds, and a number of bird behaviours were observed more frequently at open ponds (Table 3, Appendix B.1, B.2). At the open ponds, foraging was a particularly important activity, and was significantly more prevalent at open ponds compared to overgrown ponds $(t=2.44$, $\mathrm{df}=10, p=0.03$ ), especially amongst open country, insectivorous species such as swallows, swifts and whitethroats. Further, many open-country bird species such as linnet, yellowhammer, reed bunting, house sparrow and greenfinch, as well as the ground-nesting grey partridge and skylark, were strongly associated with the grassland buffer strips around open ponds, but did not show a similar affinity to buffer strips at overgrown ponds $(t=2.97, \mathrm{df}=10, p=0.01)$. Emergent plant stands (e.g. sedge beds), which were utilised at open ponds by ducks (Anas spp.) and warblers (Acrocephalus spp.) were furthermore widely lacking at overgrown ponds, leading to an associated absence of these species. Tree vegetation at both pond groups was important for refuge and as a perch for singing and territorial displays $(\mathrm{t}=-0.61, \mathrm{df}=10, p=0.55)$. However, breeding pairs and family groups, occasionally even nesting within the pond cluster, were observed more frequently at open ponds $(t=3.74, \mathrm{df}=10, p=0.003)$, and evidence of chick provisioning was recorded on more occasions at open ponds $(\mathrm{t}=2.5, \mathrm{df}=10, p=0.03)$. Aside from a few aquatic species such as moorhen Gallinula chloropus, the bird species encountered at overgrown ponds were largely confined to the surrounding wet woodland vegetation rather than the waterbody itself. 


\section{DISCUSSION}

\subsection{Drivers of avian diversity at farmland ponds}

321 Similar to previous studies (Froneman et al. 2001, Sebastián-Gonzaléz et al. 2010), larger ponds possessed a larger pool of bird species. The most species-rich ponds however were not only large, but also harboured abundant and spatially heterogeneous macrophyte communities. Macrophytes are extremely important components of pond ecosystems, with high macrophyte coverage exerting a significant positive influence on overall aquatic diversity (McAbendroth et al. 2005, Thomaz \& da Cunha 2010, Florencio et al. 2014). Generally, the influence of open-canopy, macrophyte-dominated ponds on both aquatic and terrestrial species has to date largely evaded scientific research. Our results show that the abundance and diversity (species richness) of birds encountered in the direct vicinity of ponds was strongly positively influenced by macrophyte coverage, and strongly negatively associated with high levels of shading, although it is difficult to identify underlying causal relationships.

Under conditions of high tree/scrub shading at late-successional unmanaged ponds, aquatic plants are typically eliminated. By contrast, management-induced reductions in shading lead to a rapid, positive response of aquatic macrophytes in terms of both species cover and diversity (Sayer et al. 2012). Presence of vegetation within ponds is cited as an important factor for waterbirds when selecting wetland habitat (Cody 1985, Sebastián-González et al. 2010), since increased macrophyte cover provides benefits such as food, nesting material, habitat and refuge from predators (McKinstry \& Anderson 2002, Santoul et al. 2009). Our results show that such benefits extend beyond waterbirds to birds encountered across agricultural landscapes more generally, covering open country, ground nesting, reed nesting, granivorous and insectivorous guilds, all of which appeared to associate with, and potentially benefit from, open-canopy, macrophyte-dominated ponds and their connected grassland buffers. Notably, open-canopy ponds appeared to offer suitable habitat for a number of UK BAP conservation-priority farmland species and species undergoing declines on farmland, such as skylark, grey partridge and reed bunting, all of which were primarily associated with open ponds, but were absent at overgrown ponds. The habitat associations of these species suggest that individuals can find some of the nesting or foraging resources required for their persistence in or around open ponds. 
349 The higher richness and abundance of bird species using open-canopy ponds could be the result of a variety of ecological mechanisms, particularly those relating to habitat complexity, the high degree of habitat variation among individual managed ponds and increased food availability. Aquatic invertebrates are known to establish much more diverse communities in structurally-complex macrophyte stands associated with open ponds, which results in both a greater diversity and abundance of adult stages (Gee et al. 1997, McAbendroth et al. 2005, Hinden et al. 2005), and following emergence and dispersal from the pond may form an important food subsidy for foraging insectivorous birds (Schummer et al. 2012, Dreyer et al. 2015, Fig.6). Key potential invertebrate prey taxa include the orders Odonata, Ephemeroptera and Coleoptera, and the family Chironomidae. In our study, we did not quantify emergent invertebrate abundance or diversity; however, our previous research showed that, with the exception of molluscs, managed Manor Farm ponds showed higher invertebrate diversity than unmanaged ponds, with invertebrate diversity steadily increasing for 3-5 years after management (Sayer et al. 2012). In our present study, observations at open ponds suggested that adult invertebrate prey were abundant. Aerial insectivores such as swallows, swifts and house martins seemed primarily driven by emerging invertebrates, and pairs or groups were frequently observed hovering, diving and catching insects on the wing over open water (as in Fig.2b). Invertebrate resources offered by ponds may become particularly important during the breeding season, when nutritional requirements are elevated. A number of whitethroat nests were encountered in the bushes fringing open canopy ponds and adults were regularly observed provisioning young. Nesting sites adjacent to open ponds may have been favoured by this species to allow better access to invertebrate-rich foraging sites when provisioning offspring.

370 A variety of grasses, sedges, rushes and herbs of different heights and structures were encountered 371 around the open ponds (Fig.2a, b), which may offer nesting materials, seed resources, refuge from 372 predators and resting and perching habitat, as well as important habitat for invertebrate prey. Josefsson et al. (2013) observed that fields with grassland buffer strips supported significantly more

374 skylark territories than fields without buffer strips, with such sites characterized by increased densities of spiders and beetles. Thus, for farmland birds that rely on the cropped area of fields for both breeding and foraging (such as skylark), grassland buffer strips around isolated, open farmland ponds 
could play an important supplementary role in terms of food resources, provided that there is a sufficient density of ponds in the landscape. In a pondscape setting, we suggest that surrounding grassland margins may act as recipients of particularly high numbers of invertebrate prey originating from the pond, with invertebrate assemblages in these buffers further enhanced by the presence of humidity gradients from the pond margin towards agricultural habitats on higher ground (Fig.6a). Seeds associated with pond marginal areas may also form an important part of the diet of many conservation priority granivores on farmland, including house sparrow, yellowhammer and linnet (Atkinson et al. 2004, Robinson et al. 2004, McCracken \& Tallowin 2004). A key, known bottleneck for farmland birds is starvation in late winter, a phenomenon known as the "winter hungry gap" (Siriwardena et al. 2008). It is possible that particularly open, plant-rich ponds may provide a seedrich area that persists through winter and thus assists bird survival. In contrast, the grass and dicot seeds involved would not be available in overgrown habitats because both the plants and birds concerned are open country species: the plants are not found in shaded conditions and the birds forage in open areas, not within woody vegetation.

The lower species diversity observed at overgrown ponds is probably due to the relative homogeneity of habitats offered by such ponds, which essentially mimic small wet woodland sites. Although the overgrown ponds were also surrounded by grassland buffers, these apparently failed to offer birds the same benefits as grassland buffers around open ponds, possibly because the grassland was heavily shaded and separated from the pond by a dense barrier of woody vegetation (Fig.2c, 6b). Open country species often avoid vertical structures (Sparks et al. 1996), rendering areas immediately around densely wooded ponds unattractive to these species. It follows that another possible cause of lower avian diversity at overgrown ponds is a perceived heightened risk of ambush from predators around dense cover, particularly for open country species (Cresswell 1996). Although it will not have represented a real predatory threat, a tawny owl observed at overgrown pond S7 may have affected what was detected there: this pond was distinct from the other overgrown ponds not least in supporting the lowest number of bird species.

It could be argued that a lack of bird diversity observed amongst the overgrown ponds was partly an artefact of reduced visibility at overgrown ponds. However, while birds may not always have been seen at these ponds, hidden birds still had a high chance of detection by their vocalisations. Clearly, 
overgrown ponds also afforded good habitat for woodland birds. In this respect, they may be used as stepping stones for species travelling between larger woodland sites (Neuschultz 2013). Therefore, maintaining some overgrown ponds should have positive implications for habitat connectivity, promoting the dispersal of woodland species (Lawton et al. 2010).

\subsection{Pond management and farmland bird conservation}

411 This study suggests that pond management can be considered to be a valuable tool for bird conservation in farmland. It also alludes to the importance of maintaining a mosaic of pond successional stages within agricultural landscapes in order to support a wide variety of bird guilds. However, the relative value of each successional stage will depend on the extent to which it contributes to the existing habitat heterogeneity in a given landscape. The continued terrestrialisation of entire agricultural pondscapes risks eliminating the contribution of open ponds to landscape-level avian diversity. Equally, simultaneous, uniform pond management with associated loss of wet woodland habitat and homogenisation of the pondscape could have detrimental effects for woodland guilds, particularly declining wet woodland species such as marsh tit, which was uniquely associated with semi-overgrown ponds in this study. We recommend that a high level of environmental variability should be maintained across agricultural pondscapes, taking resource and habitat requirements of specialist bird groups most at risk from future declines into account (Gregory et al. 2004, Le Viol 2012).

424 Clearly, the Manor Farm approach of arresting succession at just a few ponds every year, with some ponds left to natural development, ensures the existence of a pond mosaic comprising ponds of varying stages of succession, which could provide an ideal scenario for farmland bird conservation. In other regions, where ponds are less abundant, creation of new ponds could be required to provide new habitat for local bird populations. We predict that the benefits of pond management for biodiversity are by no means confined to the aquatic environment or even the immediate vicinity of the pond. Instead, where many open ponds are present, high rates of aquatic invertebrate deposition and dispersal may significantly increase invertebrate abundance and diversity across the entire landscape through a strong "chimney effect" (Fig.6a). As aquatic and terrestrial ecosystems are tightly linked (Knight et al. 2005), increasing the interchange of resources between aquatic and terrestrial habitats might be of paramount significance to regional biodiversity (Baxter et al. 2005, Richardson et al. 
2010), with cross-system subsidies, represented here by aquatic insect deposition and food-plant resources, being of significant importance to ecosystem functioning in farmland environments (Allen et al. 2012, Bartels et al. 2012, Dreyer et al. 2015, Soininen et al. 2015).

Further study is needed to quantify emergent invertebrate abundance and diversity at managed and un-managed ponds, as well as to determine how pond management may be optimized to enhance both breeding and overwintering of farmland birds. Our study is limited in its spatial and temporal coverage, and we suggest that future bird, macrophyte and invertebrate surveys are carried out at different times of the year to account for seasonal variability. This should lead to much improved understanding of the role of ponds for farmland bird conservation. Nevertheless, our study strongly suggests that pond management has a very important role to play in this respect. Ponds are cheap and simple to manage compared to other habitats, yet they remain a rarely promoted option within AES. We propose that more emphasis be placed on the value of ponds and their management within agricultural policy, environmental education and conservation strategies, within and across the farmed landscape.

\section{Acknowledgements}

452 We wish to thank all the landowners of the farms used in this study for permitting us to survey their

453 ponds, E.Smith for assistance with field work and D. and J.Sayer for much logistical support. We also thank the UCL Environmental Change Research Centre for financial support, G. Hilton (WWT) and S.Newson (BTO) for advice on bird survey methods, and the UCL MSc in Conservation for general facilitation. We dedicate this study to R.Waddingham at Manor Farm, who came up with all the ideas that underpin this work. The dedication and care he demonstrates towards his ponds show that nature conservation and modern agriculture can coexist in a highly sustainable way - a powerful and much needed message. 


\section{Literature Cited}

Allen, D.C., Vaughn, C.C., Kelly, J.F., Cooper, J.T., Engel, M.H., 2012. Bottom-up biodiversity effects increase resource subsidy flux between ecosystems. Ecology, 93, 2165-2174.

Atauri, J.A., de Lucio, J.V., 2001. The role of landscape structure in species richness distribution of birds, amphibians, reptiles and lepidopterans in Mediterranean landscapes. Landscape Ecology,16, 147-59.

Atkinson, P.W., Buckingham, D.L., Morris, A.J., 2004. What factors determine where invertebratefeeding birds forage in dry agricultural grasslands? In: Ecology and Conservation of Lowland Farmland Birds II: The Road to Recovery. Ibis, 146 (Suppl. 2), 99-107.

Baillie, S.R., et al. 2014. BirdTrends 2014: trends in numbers, breeding success and survival for UK breeding birds. Research Report 662. BTO, Thetford. http://www.bto.org/birdtrends

Baker, D.J., Freeman, S.N., Grice, P.V., Siriwardena, G.M., 2012. Landscape-scale responses of birds to agri-environment management: a test of the English Environmental Stewardship scheme. Journal of Applied Ecology, 49, 871-882.

Barker, A.M., 2004. Insects as food for farmland birds: is there a problem? In: van Emden, H.F., Rothschild, M. (Eds.), Insects and Bird Interactions. Intercept, Andover, pp. 37-50.

Bartels, P., Cucherousset, J., Steger, K., Eklöv, P., Tranvik, L.J., Hillebrand, H., 2012. Reciprocal subsidies between freshwater and terrestrial ecosystems structure consumer resource dynamics. Ecology, 93, 1173-1182.

Baxter, C., Fausch, V.K.D., Saunders, W.C., 2005. Tangled webs: reciprocal flows of invertebrate prey link streams and riparian zones. Freshwater Biology, 50, 201-220.

Bennett, A.F., Radford, J.Q., Haslem, A., 2006. Properties of land mosaics: implications for nature conservation in agricultural environments. Biological Conservation, 133, 250-264. 
Benton, T.G., Bryant, D.M., Cole, L., Crick, H.P.Q., 2002. Linking agricultural practise to insect and

Benton, T.G., Vickery, J.A., Wilson, J.D., 2003. Farmland biodiversity: is habitat heterogeneity the key? Trends in Ecology and Evolution, 18, 182-188.

Bibby, C.J., Burgress, N.D., Hill, D.A., 1992. Bird Census Techniques. Academic Press, London.

Biggs, J., Williams, P., Whitfield, M., Nicolet, P., Weatherby, A., 2005. 15 years of pond assessment in

Britain: results and lessons learned from the work of Pond Conservation. Aquatic Conservation:

Marine and Freshwater Ecosystems, 15, 693-714.

BTO (The British Trust for Ornithology), 2014. Garden birdwatch: our methods. (WWW) BTO, landscape context and agricultural intensification. Landscape and Urban Planning, 67, 195-204.

Butler, S.J., Vickery, J.A., Norris, K., 2007. Farmland biodiversity and the footprint of agriculture. Science, 315, 381-384.

505

506

Céréghino, R., Ruggerio, A., Marty, P., Angélibert, S., 2008. Biodiversity and distribution patterns of freshwater invertebrates in farm ponds of a south-western French agricultural landscape. Hydrobiologia, 597, 43-51.

509 Céréghino, R., Boix, D., Cauchie, H.M., Martens, K., Oertli, B., 2014. The ecological role of ponds in a changing world. Hydrobiologia, 723, 1-6.

512 Chamberlain, D.E., Fuller, R.J., Bunce, R.G.H., Duckworth, J.C., Shrubb, M., 2000. Changes in the

513 abundance of farmland birds in relation to the timing of agricultural intensification in England and

514 Wales. Journal of Applied Ecology, 37, 771-788.

516 Cody, M.L., 1985. Habitat selection in birds. Academic Press, Orlando. 
518 Colwell, R.K., 2009. Estimates S: Statistical Estimation of Species Richness and Shared Species from

519 Samples, Version 8.2, User's Guide and application, http://purl.oclc.org/estimates.

520

521 Cresswell, W., 1996. Surprise as a winter hunting strategy in sparrowhawks Accipiter nisus,

522 peregrines Falco peregrinus and merlins F.columbarius. Ibis, 138, 684-692.

523

524 Davies, B., Biggs, J., Williams, P., Whitfield, M., Nicolet, P., Sear, D., Bray, S., Maund, S., 2008a.

525 Comparative biodiversity of aquatic habitats in the European agricultural landscape. Agriculture,

526 Ecosystems and Environment, 125, 1-8.

527

528

Declerck, S. et al., 2006. Ecological characteristics of small farmland ponds: associations with land use practices at multiple spatial scales. Biological Conservation, 131, 523-532.

530

531

Donald, P.F., Green, R.E., Heath, M.F., 2001. Agricultural intensification and the collapse of Europe's

farmland bird populations. Proceedings of the Royal Society B: Biological Sciences, 268, 25-29.

533

Donald, P.F., Evans, A.D., 2006. Habitat connectivity and matrix restoration: the wider implications of agri-environment schemes. Journal of Applied Ecology, 43, 209-218.

536

Doxa, A., Bas, Y., Paracchini, M.L., Pointereau, P., Terres, J.M., Jiguet, F., 2010. Low intensity agriculture increases farmland bird abundances in France. Journal of Applied Ecology, 47, 13481356.

540

541 Dreyer, J., Townsend, P.A., Hook III, J.C., Hoekman, D., Zanden, M.J.V., Gratton, C., 2015.

542 Quantifying aquatic insect deposition from lake to land. Ecology, 96, 499-509.

543 Eaton, M.A. et al., 2013. The State of the UK's Birds 2013. RSPB, BTO, WWT, NRT, JNCC, NE, 544 NIEA and SNH, Sandy, Bedfordshire. 
546 Fahrig, L., Brotons, L., Burel, F.G., Crist, T.O., Fuller, R.J., Sirami, C., Siriwardena, G.M., Martin, J.L.,

547 2011. Functional landscape heterogeneity and animal biodiversity in agricultural landscapes. Ecology

548 Letters, 14, 101-112.

549

550 Florencio, M., Diaz-Paniagua, C., Gomez-Rodriguez, C., Serrano, L., 2014. Biodiversity patterns in a 551 macroinvertebrate community of a temporary pond network. Insect Conservation and Diversity, 7, 455221.

553

Foley, J.A., DeFries, R., Asner, G.P., 2005. Global consequences of land use. Science, 309, 570-74.

555

556

Ford, H.A., Barrett, G.W., Saunders, D.A., Recher, H.F., 2001. Why have birds in the woodlands of

Southern Australia declined? Biological Conservation, 97, 71-88.

558

559

Froneman, A., Mangnall, J., Little, R.M., Crowe, T.M., 2001. Water-bird assemblages and associated habitat characteristics of farm ponds in the Western Cape, South Africa. Biodiversity and

Conservation, 10, 251-270.

562

Fuller, R.J., Gregory, R.D., Gibbons, D.W., Marchant, J.H., Wilson, J.D., Baillie, S.R., Carter, N., 1995. Population declines and range contractions among lowland farmland birds in Britain. Conservation Biology, 9, 1425-1441.

567 Fuller, R.J., 2000. Relationships between recent changes in lowland British agriculture and farmland bird populations: an overview, in: Aebischer, N.J., Evans, A.D., Grice, P., Vickery, J.A. (Eds.), The Conservation and Ecology of Lowland Farmland Birds. Tring, British Ornithologist's Union, pp. 5-16.

571 Gee, J.H.R., Smith, B.D., Lee, K.M., Griffiths, S.W., 1997. The ecological basis of freshwater pond 572 management for biodiversity. Aquatic Conservation: Marine and Freshwater Ecosystems, 7, 91-104.

574 Gregory, R.D., Noble, D.G., Custance, J., 2004. The state of play of farmland birds: population trends and conservation status of lowland farmland birds in the United Kingdom. Ibis, 146, 1-13. 
577 Hinden, H., Oertli, B., Menetrey, N., Sager, L., Lachavanne, J.B., 2005. Alpine pond biodiversity: what 578 are the related environmental variables? Aquatic Conservation: Marine and Freshwater Ecosystems, $579 \quad 15,613-624$.

580

581 Hinsley, S.A., Bellamy, P.E., 2000. The influence of hedge structure, management and landscape 582 context on the value of hedgerows to birds: a review. Journal of Environmental Management, 60, 3358349.

584

Holland, J.M., 2004. The impact of agriculture and some solutions for arthropods and birds, in: van

586 Emden, H.F., Rothschild, M. (Eds.), Insects and Bird Interactions. Intercept, Andover. pp. 51-73. 587

588 Hurlbert, S.H., 1971. The nonconcept of species diversity: A critique and alternative parameters. 589 Ecology, 52, 577-586.

590

IBM Corp, 2011. IBM SPSS Statistics for Windows, Version 20.0. IBM Corp, Armonk, New York.

592

593 Joint Nature Conservation Committee (JNCC), 2007. Report on the Species and Habitat Review.

594 Report by the Biodiversity Reporting and Information Group (BRIG) to the UK Standing Committee 595 June 2007.

596

597 Josefsson, J., Berg, A., Hiron, M., Pätra, T., Eggers, S., 2013. Grass buffer strips benefit invertebrate 598 and breeding skylark numbers in a heterogeneous agricultural landscape. Agriculture, Ecosystems 599 and Environment, 181,101-107.

600

601 Lawton, J.H. et al., 2010. Making Space For Nature: a review of England's wildlife sites and ecological 602 network. Report to Defra. 
604 Le Viol, I., Jiguet, F., Brotons, L., Herrando, S., Lindström, Å., Pearce-Higgins, J.W., Reif, J., Van

605 Turnhout, C., Devictor, V., 2012. More and more generalists: two decades of changes in the 606 European avifauna. Biology Letters, 8, 780-782.

607

Lemmens, P., Mergeay, J., De Bie, T., Van Wichelen, J., De Meester, L., Declerck, S.A.J., 2013. How

to maximally support local and regional biodiversity in applied conservation? Insights from pond management. PLOS ONE, 8, e72538.

611

612 Kleijn, D. et al., 2006. Mixed biodiversity benefits of agri-environment schemes in five European 613 countries, Ecology Letters, 9, 243-254.

614

615

Kleijn, D., Rundlöf, M., Scheper, J., Smith, H.G., Tscharntke, T., 2011. Does conservation on farmland contribute to halting the biodiversity declines? Trends in Ecology and Evolution, 26, 474481.

618

Knight, T.M., McCoy, M.W., Chase, J.M., McCoy, K.A., Holt, R.D., 2005. Trophic cascades across ecosystems. Nature, 437, 880-883.

621

Marja, R., Herzon, I., 2012. The importance of drainage ditches for farmland birds in agricultural landscapes in the Baltic countries: does field type matter? Ornis Fennica, 89, 1-12.

Matuszak, A., Moertl, M., Quillfeldt, P., Bauer, H.G., 2014. Macrophyte-associated macroinvertebrates as an important food source for wintering waterbirds at Lake Constance. Limnology, 15, 69-76.

627

McAbendroth, L., Ramsay, P.M., Foggo, A., Rundle, S.D., Bilton, D.T., Persson, L., 2005. Does

629 macrophyte fractal complexity drive invertebrate diversity, biomass and body size distributions? Oikos, 111, 279-290.

631

632 McCracken, D.I., Tallowin, J.R., 2004. Swards and structure: the interactions between farming 633 practises and bird food resources in lowland grasslands. Ibis, 146, 170-181. 
McKinstry, M.C., Anderson, S.H., 2002. Creating wetlands for waterfowl in Wyoming. Ecological

636 Engineering, 18, 293-304.

637

Natural England, 2015. Countryside Stewardship Handbook - November 2015.

639

Neuschultz, E.L., Brown, M., Farwig, N., 2013. Frequent bird movements across a highly fragmented 641 landscape: the role of species traits and forest matrix. Animal Conservation, 16, 170-179.

642

Newton, I., 1998. Population Limitation in Birds. Academic Press, San Diego.

Palmer, M.A., Bell, S.L., Butterfield, I.A., 1992. A botanical classification of standing waters in Britain:

Perkins, A.J., Whittingham, M.J., Bradbury, R.B., Wilson, J.D., Morris, A.J., Barnett, P.R., 2000.

Habitat characteristics affecting use of lowland agricultural grassland by birds in winter. Biological

Pino, J., Rodà, F.J., Ribas, J., Pons, X., 2000. Landscape structure and bird species richness:

654 implications for conservation in rural areas between natural parks. Landscape and Urban Planning, 49, 35-48.

Pisces Conservation Ltd, 2002. Species Diversity and Richness. Version 3.02. Pisces Conservation Ltd, Lymington.

659

Prince, H.C., 1964. The origin of pits and depressions in Norfolk. Geography, 49, 15-32.

661 
665 Richardson, J.S., Zhang, Y., Marczak, L.B., 2010. Resource subsidies across the land-freshwater 666 interface and responses in recipient communities. River Research and Applications, 26, 55-66.

667

Rioux Paquette, S., Pelletier, F., Garant, D., Bélisle, M., 2014. Severe recent decrease of adult body 669 mass in a declining insectivorous bird population. Proceedings of the Royal Society B: Biological Sciences, 282, 20140649.

671

672 Robinson, R.A., Sutherland, W.J., 2002. Post-war changes in arable farming and biodiversity in Great Britain. Journal of Applied Ecology, 39, 157-176.

Robinson, R.A., Hart, J.D., Holland, J.M., Parrott, D., 2004. Habitat use by seed-eating birds: a scaledependent approach. Ibis, 146, 87-98.

677

Sabatier, R., Doyen, L., Tichit, M., 2014. Heterogeneity and the trade-off between ecological and productive functions of agro-landscapes: a model of cattle-bird interactions in a grassland agroecosystem. Agricultural Systems, 126, 38-49.

681

Santoul, F., Gaujard, A., Angélibert, S., Mastrorillo, S., Céréghino, R., 2009. Gravel pits support water-bird diversity in an urban landscape. Hydrobiologia, 634, 107-114.

Sayer, C.D., Copp, G.H., Emson, D., Godard, M.J., Zieba, G., Wesley, K.J., 2011. Towards the conservation of crucian carp Carassius carassius: understanding the extent and causes of decline within part of its native English range. Journal of Fish Biology, 79, 1608-1624.

Sayer, C.D., Andrews, K., Shilland, E., Edmonds, N., Edmonds-Brown, R., Patmore, I.R., Emson, D., 690 Axmacher, J.C., 2012. The role of pond management for biodiversity conservation in an agricultural 691 landscape. Aquatic Conservation: Marine and Freshwater Ecosystems, 22, 626-638. 
Sayer, C.D., Shilland, E., Greaves, H., Dawson, B., Patmore, I.R., Emson, D., Alderton, E., Robinson, a Norfolk farm. British Wildlife, 25 (1), 21-28.

696

Scherr, S.J., McNeely, J.A., 2008. Biodiversity conservation and agricultural sustainability: towards a new paradigm of 'ecoagriculture' landscapes. Philosophical Transactions of the Royal Society B:

700

701

Schummer, M.L., Palframan, J., McNaughton, E., Barney, T., Petrie, S.A., 2012. Comparisons of bird, 702 aquatic macroinvertebrate and plant communities among dredged ponds and natural wetland habitats at Long Point, Lake Eerie, Ontario. Wetlands, 32, 945-953.

704

Sebastián-González, E., Sánchez-Zapata, J.A., Botella, F., 2010. Agricultural ponds as alternative 706 habitat for waterbirds: spatial and temporal patterns of abundance and management strategies. European Journal of Wildlife Research, 56, 11-20.

708

Siriwardena, G.M., Calbrade, N.A., Vickery, J.A., 2008. Farmland birds and late winter food: does seed supply fail to meet demand? Ibis, 150, 585-595.

Soininen, J., Bartels, P., Heino, J., Luoto, M., Hillebrand, H., 2015. Toward more integrated ecosystem research in aquatic and terrestrial environments. BioScience, 65,174-182.

Sparks, T.H., Parish, T., Hinsley, S.A., 1996. Breeding birds in field boundaries in an agricultural landscape. Agriculture, Ecosystems and Environment, 60, 1-8.

Stenroth, K., Polvi, L.E., Fältström, E., Jonsson, M., 2015. Land-use effects on terrestrial consumers through changed size structure of aquatic insects. Freshwater Biology, 60, 136-149. 
721 Stoate, C., Báldi, A., Beja, P., Boatman, N.D., Herzin, I., van Doorn, A., de Snoo, G.R., Rakosy, L.,

722 Ramwell, C., 2009. Ecological impacts of early $21^{\text {st }}$ century agricultural change in Europe - A review.

723 Journal of Environmental Management, 91, 22-46.

724

725 ter Braak, C., Smilauer, P., 2002. CANOCO reference manual and CanoDraw for Windows user's

726 guide: software for canonical community ordination (version 4.5). Microcomputer Power, Ithaca, New

727 York.

728

729 Thomaz, S.M., da Cunha, E.R., 2010. The role of macrophytes in habitat structuring in aquatic

730 ecosystems: methods of measurement, causes and consequences on animal assemblages'

731 composition and biodiversity. Acta Limnologica Brasiliensia, 22, 218-236.

732

733

Toms, M., 2004. Garden Birdwatch Handbook. British Trust for Ornithology, BTO, Thetford.

734

735

Tscharntke, T., Klein, A.M., Kruess, A., Steffan-Dewenter, I., Thies, C., 2005. Landscape perspectives

736 on agricultural intensification and biodiversity: ecosystem service management. Ecology Letters, 8 , 857-874.

738

van Zanten, B.T. et al., 2014. European agricultural landscapes, common agricultural policy and ecosystem services: a review. Agronomy for Sustainable Development, 34, 309-325.

Weibull, A.C., Östman, O., Granqvist, A., 2003. Species richness in agroecosystems: the effect of landscape, habitat and farm management. Biodiversity and Conservation, 12, 1335-1355.

Welsh Government, 2015. Glastir Entry Booklet 2: Technical Guidance 2015.

747 Whittingham, M.J., Krebs, J.R., Swetnam, R.D., Thewlis, R.M., Wilson, J.D., Freckleton, R.P. 2009.,

Habitat associations of British breeding farmland birds. Bird Study, 56, 43-52. 
749 Williams, P., Whitfield, M., Biggs, J., Bray, S., Fox, G., Nicolet, P., Sear, D., 2004. Comparative

750 biodiversity of rivers, streams, ditches and ponds in an agricultural landscape in Southern England.

751 Biological Conservation, 115, 329-341.

752 Williams, P., Biggs, J., Nicolet, P., 2010. New clean-water ponds - a way to protect freshwater

753 biodiversity. British Wildlife, 22, 77-85.

754 Wood, P.J., Greenwood, M.T., Agnew, M.D., 2003. Pond biodiversity and habitat loss in the UK. Area, $755 \quad 35,206-216$.

756

757

758

759

760

761

762

763

764

765

766

767

768

769

770 
773 Fig.1 Map of the farmland study area in Norfolk, eastern England, highlighting the open, managed 774 ponds (W prefix) and overgrown ponds (D, M, S prefix) included in the study.

775 Fig.2 An open, managed pond (pond W10 in Fig.1) at Manor Farm (a); swifts (Apus apus) feeding 776 over pond W10 in May 2015 after a hatch of mayflies (b); a typical overgrown, highly terrestrialised 777 pond in the study area (c)

778 Fig.3 Hurlbert rarefaction curves for overgrown ponds, open ponds and all ponds combined. Number 779 of individuals sampled plotted against number of species encountered with error bars representing the standard error $( \pm S E)$

781 Fig.4 Correspondence Analysis (CA) of pond sites (a) and bird species (b) data. Ponds are coded 782 according to treatment (open, managed or overgrown, unmanaged)

783 Fig.5 Canonical Correspondence Analysis (CCA) showing site (a) and species (b) data. Ponds are 784 coded according to treatment (open, managed or overgrown, unmanaged)

785

Fig.6 Conceptual diagrams depicting habitat features and resources for farmland birds at typical a) open managed ponds (a) and overgrown ponds (b) 


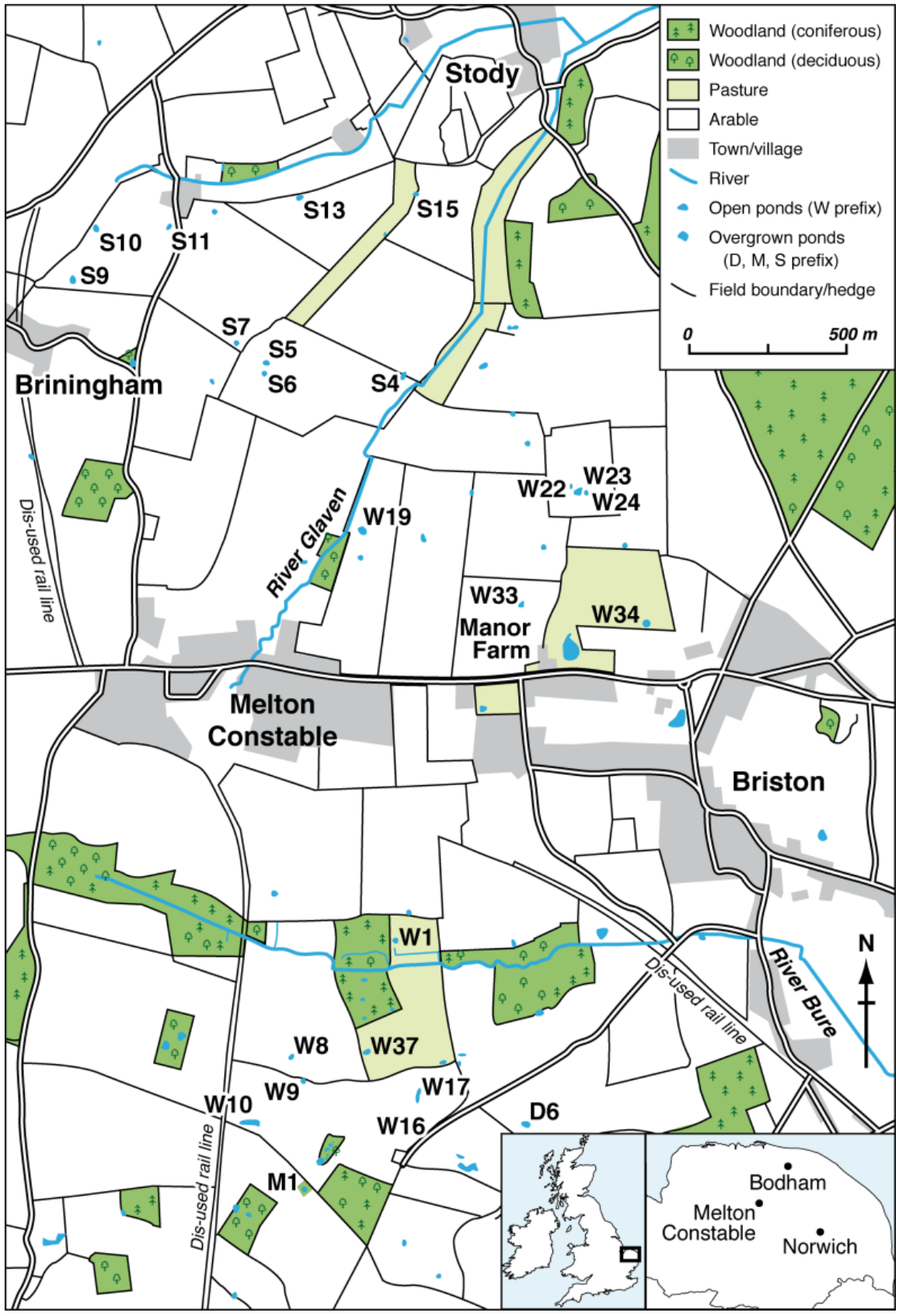

811

812

813

814

815 
818
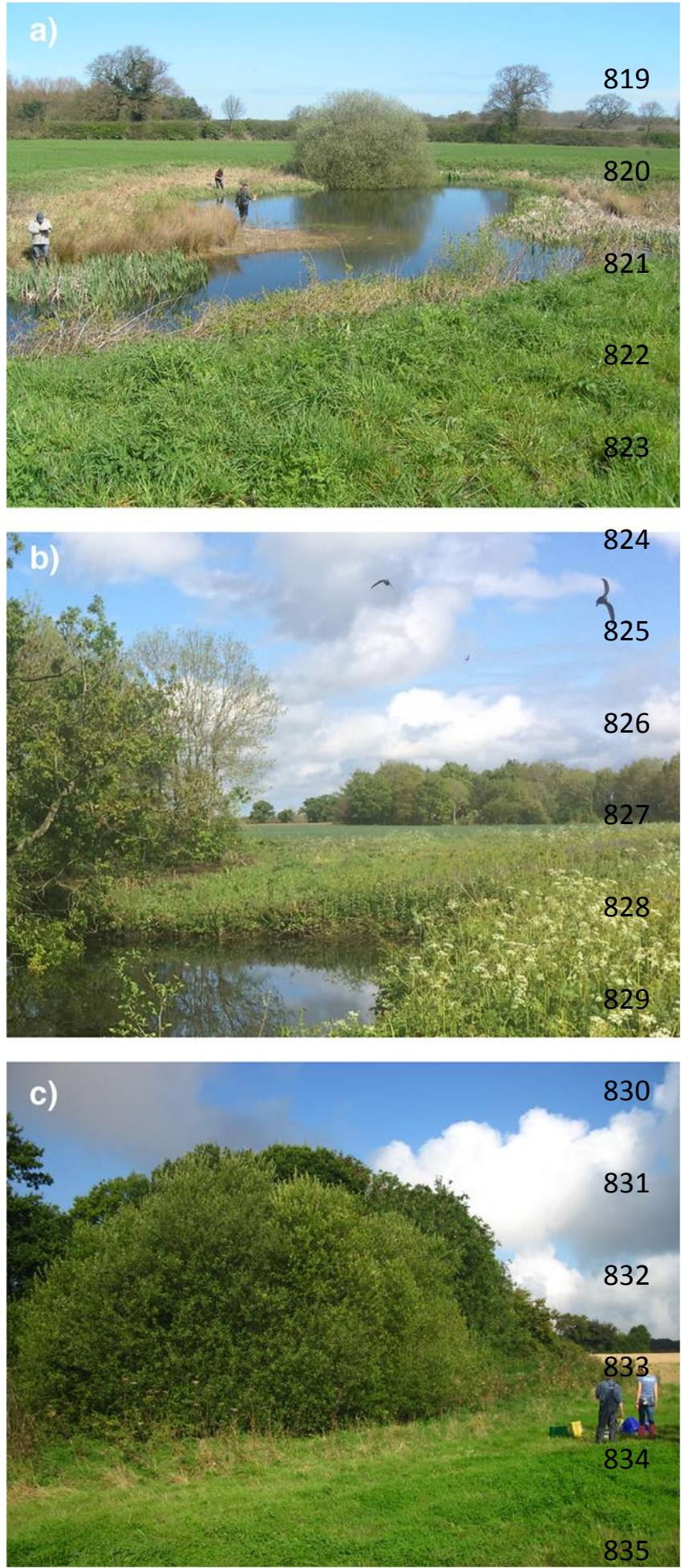

836

837 


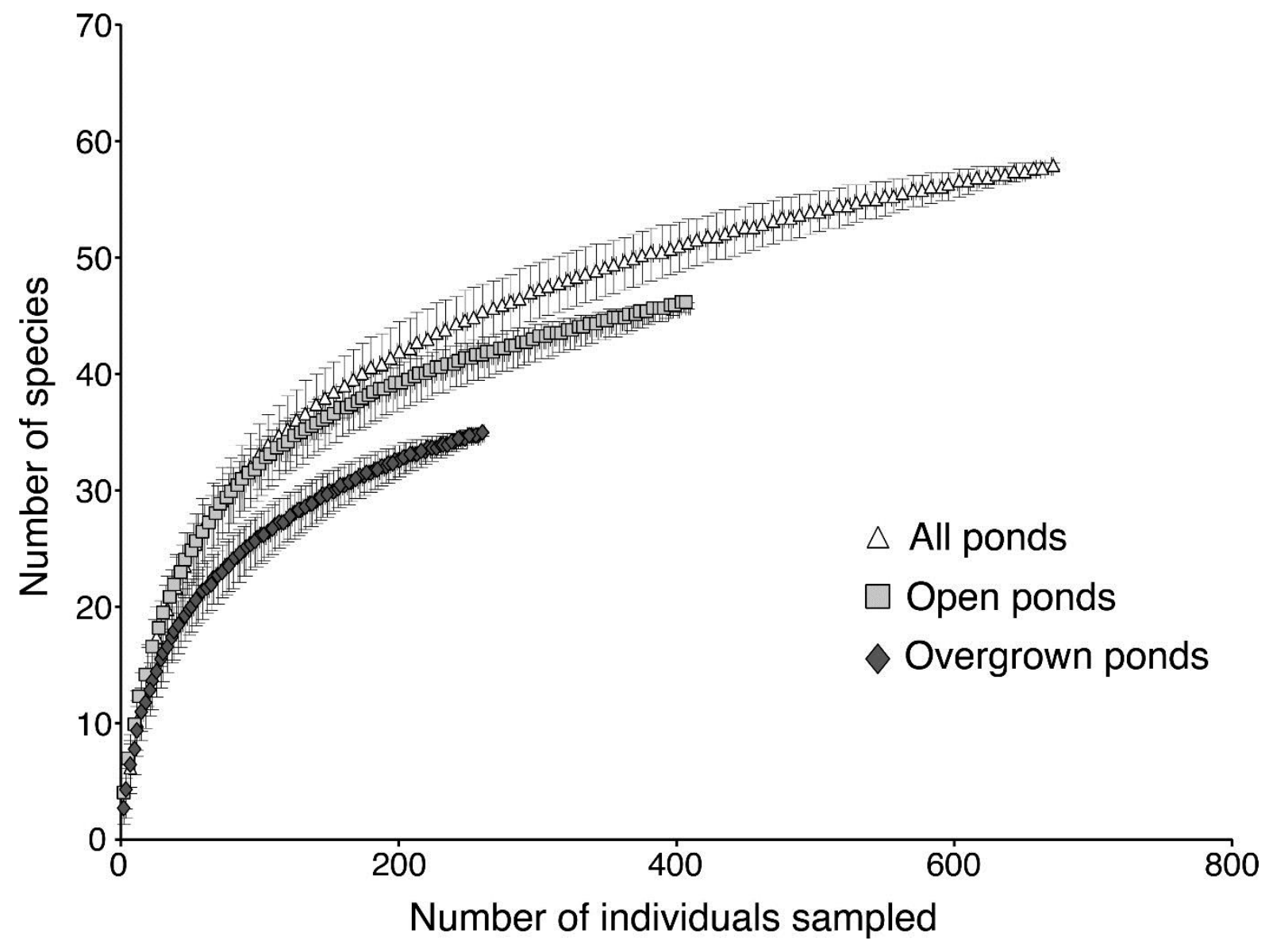

839

840

841

842

843

844

845

846

847 

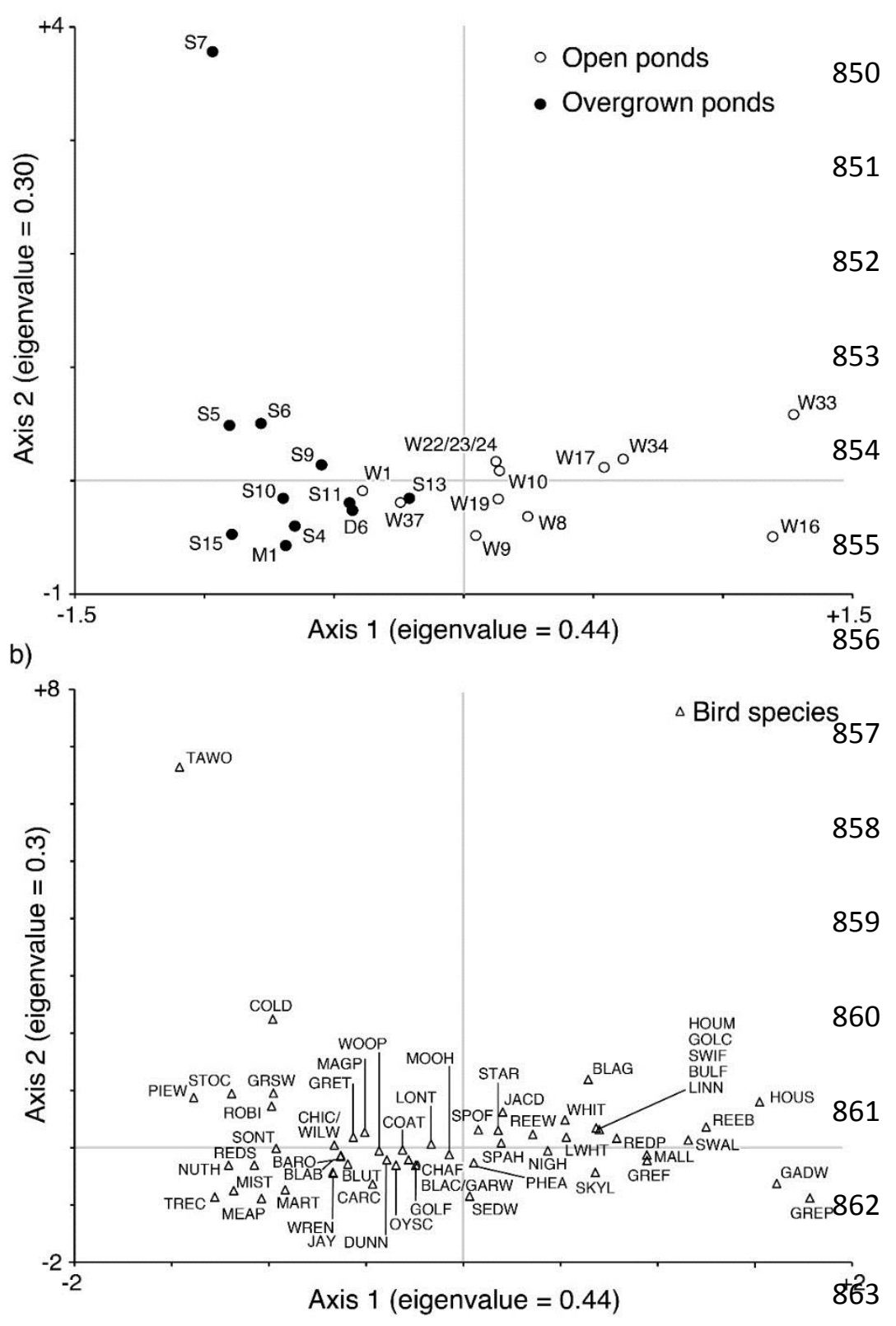

864

865 Key to species codes: BARO: barn owl, BLAB: blackbird, BLAC: blackcap, BLAG: black-headed gull, BLUT: blue tit, BULF:

866 bullfinch, CARC: carrion crow, CHAF: chaffinch, CHIC: chiffchaff, COAT: coal tit, COLD: collared dove, DUNN: dunnock,

867 GADW: gadwall, GARW: garden warbler, GOLC: goldcrest, GOLF: goldfinch, GREF: greenfinch, GREP: grey partridge, GRET:

868 great tit, GRSW: great-spotted woodpecker, HOUM: house martin, HOUS: house sparrow, JACD: jackdaw, JAY: jay, LINN:

869 linnet, LWHT: lesser whitethroat, LONT: long-tailed tit, MAGP: magpie, MALL: mallard, MART: marsh tit, MEAP: meadow pipit,

870 MIST: mistle thrush, MOOH: moorhen, NUTH: nuthatch, NIGH: nightingale, OYSC: oystercatcher, PHEA: pheasant, PIEW: pied

871 wagtail, REDP: red-legged partridge, REDS: redstart, REEB: reed bunting, REEW: reed warbler, ROBI: robin, SEDW: sedge

872 warbler, SKYL: skylark, SPAH: sparrowhawk, SPOF: spotted flycatcher, SONT: song thrush, STAR: starling, STOC: stonechat,

873 SWAL: swallow, SWIF: swift, SYLV: Sylvia/unidentified warbler (genus), TAWO: tawny owl, TREC: treecreeper, WHIT:

874 whitethroat, WILW: willow warbler, WOOP: wood pigeon, WREN: wren, YELH: yellowhammer, YELW: yellow wagtail. 
a)
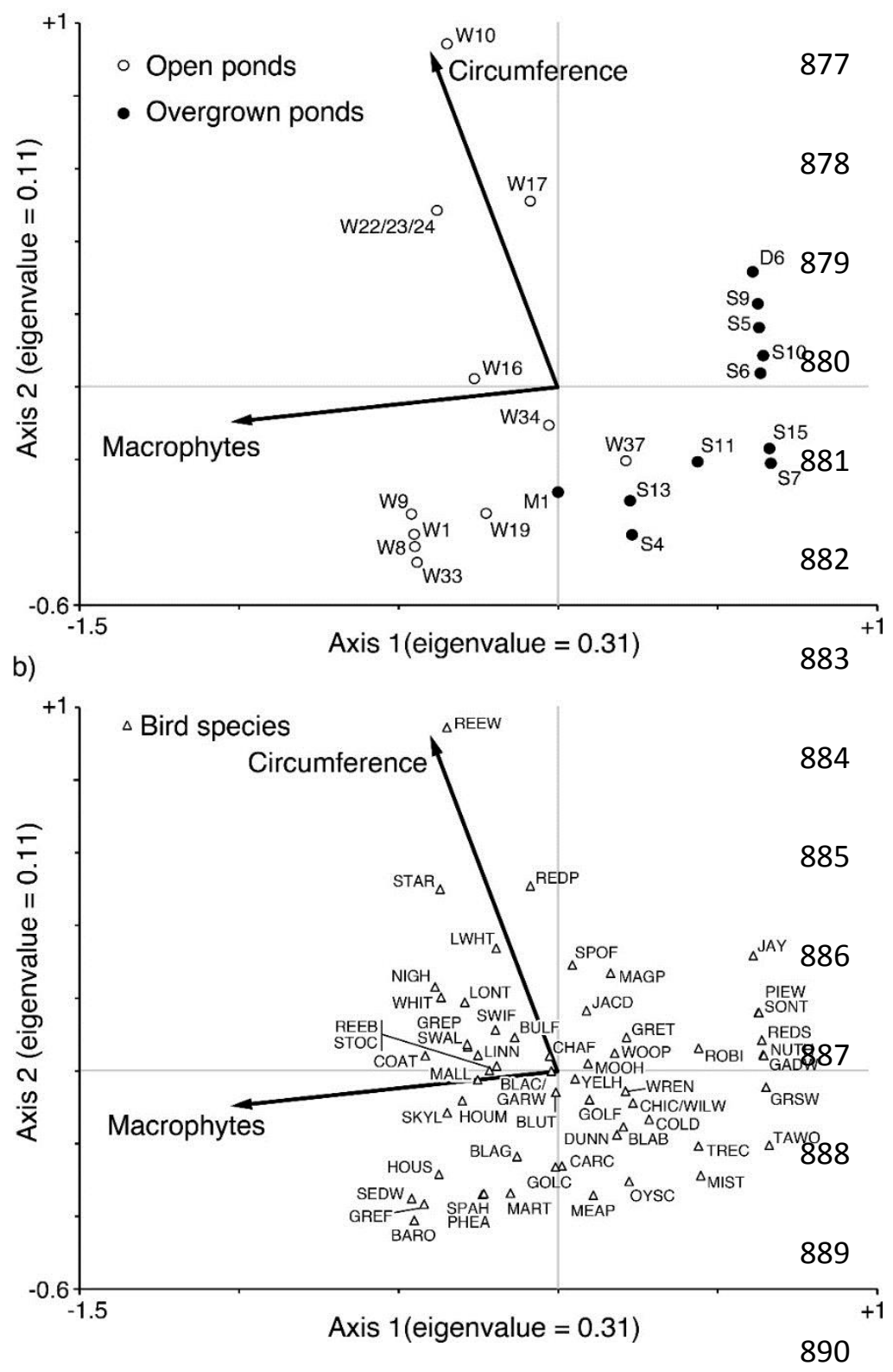

891 Key to species codes: BARO: barn owl, BLAB: blackbird, BLAC: blackcap, BLAG: black-headed gull, BLUT: blue tit, BULF:

892 bullfinch, CARC: carrion crow, CHAF: chaffinch, CHIC: chiffchaff, COAT: coal tit, COLD: collared dove, DUNN: dunnock,

893 GADW: gadwall, GARW: garden warbler, GOLC: goldcrest, GOLF: goldfinch, GREF: greenfinch, GREP: grey partridge, GRET:

894 great tit, GRSW: great-spotted woodpecker, HOUM: house martin, HOUS: house sparrow, JACD: jackdaw, JAY: jay, LINN:

895 linnet, LWHT: lesser whitethroat, LONT: long-tailed tit, MAGP: magpie, MALL: mallard, MART: marsh tit, MEAP: meadow pipit,

896 MIST: mistle thrush, MOOH: moorhen, NUTH: nuthatch, NIGH: nightingale, OYSC: oystercatcher, PHEA: pheasant, PIEW: pied

897 wagtail, REDP: red-legged partridge, REDS: redstart, REEB: reed bunting, REEW: reed warbler, ROBI: robin, SEDW: sedge

898 warbler, SKYL: skylark, SPAH: sparrowhawk, SPOF: spotted flycatcher, SONT: song thrush, STAR: starling, STOC: stonechat,

899 SWAL: swallow, SWIF: swift, SYLV: Sylvia/unidentified warbler (genus), TAWO: tawny owl, TREC: treecreeper, WHIT:

900 whitethroat, WILW: willow warbler, WOOP: wood pigeon, WREN: wren, YELH: yellowhammer, YELW: yellow wagtail. 
a) Open pond

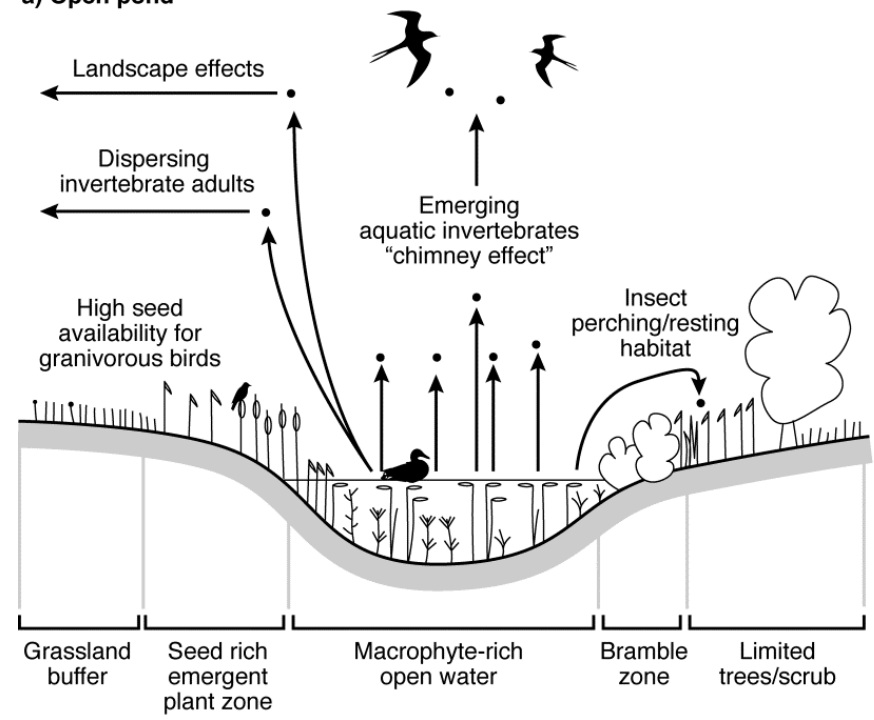

b) Overgrown pond

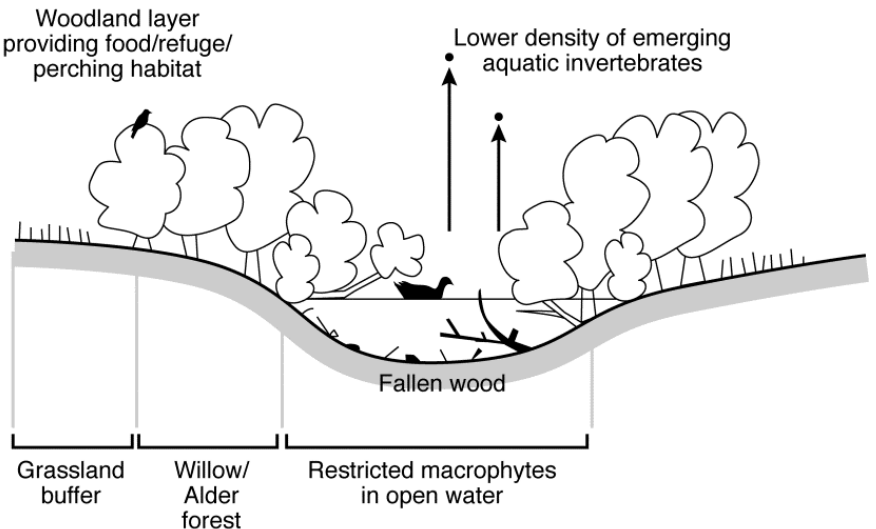

903

904

905

906

907

908

909

910

911

912 
914 Table 1. Diversity and abundance measures comparing avian alpha diversity of open and overgrown

915 ponds and gamma diversity of birds from all ponds, where figures for alpha diversity measures

916 represent mean values \pm standard error of the mean.

917

Pond category

$\begin{array}{llll}\text { Species } & \text { Abundance } & \text { Shannon's } & \text { Simpson's } \\ \text { Richness } & (\text { no. individuals }) & \text { Diversity } & \text { Diversity } \\ (x \pm \mathrm{SE}) & (x \pm \mathrm{SE}) & (x \pm \mathrm{SE}) & (x \pm \mathrm{SE})\end{array}$

Alpha Diversity

\begin{tabular}{|c|c|c|c|c|}
\hline Open & $17.5 \pm 1.4^{*}$ & $38.3 \pm 3.8^{a}$ & $13.7 \pm 0.9^{b}$ & $16.6 \pm 1.5^{b}$ \\
\hline Overgrown & $13.3 \pm 0.7^{*}$ & $24.4 \pm 1.8^{a}$ & $11.5 \pm 0.7^{b}$ & $18.2 \pm 1.8^{b}$ \\
\hline
\end{tabular}

Gamma Diversity

All Ponds

58

679

31.4

24.1

918 Combined Open

46

421

28.8

23.2

919

920

Combined Overgrown

35

268

21.1

17.6

921 Statistical significance of independent samples t-tests comparing alpha diversity means of open and

922 overgrown ponds are based on the $p$-value threshold of $p<0.05$ and are denoted by *,a,b 
924 Table 2. Stepwise Multiple Linear Regression (MLR) showing results for effects of i)

925 Submerged/floating macrophyte coverage and ii) Circumference on test variables a) Species

926 richness, b) Abundance and c) Shannon's diversity.

Beta

Test Variable and Predictors

Coefficient t-value $p$-value

a) Species richness

i) Submerged/floating macrophyte

coverage

$0.74 \quad 2.15 \quad 0.044^{*}$

ii) Circumference

0.06

$3.510 .0002^{*}$

Adjusted $\mathrm{R}^{2}=0.51, \mathrm{~F}_{(2,19)}=11.82, \mathrm{p}=0.0004^{*}$

b) Abundance

i) Submerged/floating macrophyte

coverage

$2.31 \quad 2.32 \quad 0.03^{*}$

ii) Circumference

$0.18 \quad 3.51 \quad 0.002^{*}$

Adjusted $\mathrm{R}^{2}=0.52, \mathrm{~F}_{(2,19)}=12.32, \mathrm{p}=0.0003^{*}$

c) Shannon's diversity

i) Submerged/floating macrophyte

coverage

$\begin{array}{lll}0.35 & 1.22 & 0.35\end{array}$

ii) Circumference

$0.04 \quad 2.74 \quad 0.01^{*}$

Adjusted $R^{2}=0.32, F_{(2,19)}=5.96, p=0.009^{*}$

927 Statistical significance is based on the $p$-value threshold of $p<0.05$ and is denoted by * 
928 Table 3. Frequencies of behaviours and locations of birds recorded at open and overgrown ponds.

929 Values are given as means \pm standard error of the mean (SEM) of the 11 open ponds and 11

930 overgrown ponds, along with corresponding t-values from the independent samples t-tests.

931

932

Behaviours observed

Recorded locations of birds

Foraging Provisioning Pair/family Grassland Tree

offspring groups buffer vegetation

$\begin{array}{llllll}\text { Open } & 15.6 \pm 4.1 & 4.18 \pm 1.4 & 25.5 \pm 4 & 6.45 \pm 2.2 & 33.8 \pm 6.2 \\ \text { Overgrown } & 5.36 \pm 1.3 & 0.63 \pm 0.3 & 8.27 \pm 1.6 & 0.1 \pm 0.1 & 38.7 \pm 2.7 \\ \text { t- value } & 2.44^{*} & 2.5^{\star} & 3.74^{a} & 2.97^{\mathrm{a}} & -0.61\end{array}$

933

934 Statistical significance for independent samples t-tests is based on the $p$-value threshold of $p<0.05$

935 and is denoted by *,a

$936{ }^{*} p<0.05,{ }^{a} p<0.01$

937

938

939

940

941 
Table A.1 Species records for both open managed and overgrown, non-managed ponds. Species are grouped according to guild or habitat preference and sub-

944 divided into families and allies.

945

Common Name

Open Ponds ${ }^{b}$

Overgrown Ponds ${ }^{b}$

\begin{tabular}{|c|c|c|c|c|}
\hline \multirow[t]{3}{*}{ Waterfowl and Rallids } & Anas platyrhynchos & Mallard & $\begin{array}{l}\text { W9(1), W16(3), W17(3), W19(2), } \\
\text { W33(1), W22/23/24(1), W34(1) }\end{array}$ & \multirow[b]{3}{*}{$\mathrm{S} 5(1), \mathrm{D} 6(1), \mathrm{S} 9(4), \mathrm{S} 10(2), \mathrm{S} 11(3), \mathrm{S} 13(4)$} \\
\hline & Anas strepera & Gadwall & W16(2), W34(1) & \\
\hline & Gallinula chloropus & Moorhen & $\begin{array}{l}\text { W8(1), W9(4), W10(4), W16(3), W17 } \\
\text { (4), W19(3), W22/23/24(2), W33(3), } \\
\text { W34(2), W37(3) }\end{array}$ & \\
\hline \multirow[t]{5}{*}{$\begin{array}{l}\text { Seed Eating }{ }^{\text {a }} \text { Finches } \\
\text { and Allies }\end{array}$} & Carduelis cannabina & Linnet $^{\star}$ & $\begin{array}{l}\text { W10(1), W22/23/24(1), W33(2), } \\
\text { W34(1) }\end{array}$ & \multirow{3}{*}{$M(1), S 4(2), D 6(1), S 9(1), S 11(1), S 13(1)$} \\
\hline & Carduelis carduelis & Goldfinch & $\begin{array}{l}\text { W1(1), W10(1), W16(3), W19(1), } \\
\text { W22/23/24(3), W34(1), W37(3) }\end{array}$ & \\
\hline & Chloris chloris & Greenfinch & W8(1), W9(1), W16(1), W33(1), & \\
\hline & Emberiza citrinella & Yellowhammer* & $\begin{array}{l}\text { W8(3), W9(1), W10(2), W16(3), } \\
\text { W17(4), W19(1), W22/23/24(2), } \\
\text { W33(3), W37(1) }\end{array}$ & $\begin{array}{l}\text { S4(3), S5(1), D6(1), S6(1), S7(3), S9(1), } \\
\text { S10(1), S11(2), S13(1), S15(3) }\end{array}$ \\
\hline & Fringilla coelebs & Chaffinch & $\begin{array}{l}\text { W1(2), W8(4), W9(2), W10(5), W16 } \\
(3), W 17(4), W 19(1), W 22 / 23 / 24(4),\end{array}$ & $\begin{array}{l}\text { M1(1), S4(1), S5(2), D6(4), S6(1), S7(4), } \\
\text { S9(4), S10(4), S11(4), S13(2), S15(5) }\end{array}$ \\
\hline
\end{tabular}




\begin{tabular}{|c|c|c|c|c|}
\hline \multirow{4}{*}{ Reed Nesting } & & & \multicolumn{2}{|l|}{ W33(2), W34(3), W37(3) } \\
\hline & Passer domesticus & House Sparrow* & \multicolumn{2}{|l|}{ W23(2), W33(1) W34(2) } \\
\hline & Pyrrhula pyrrhula & Bullfinch* & \multicolumn{2}{|l|}{ W22/23/24(1), W4(1) } \\
\hline & Emberiza schoeniclus & Reed Bunting* & \multicolumn{2}{|l|}{$\begin{array}{l}\text { W16(1), W17(3), W23(1), W33(2), } \\
\text { W34(1) }\end{array}$} \\
\hline \multirow{4}{*}{$\begin{array}{l}\text { Seed Eating } \\
\text { Grass Nesting }\end{array}$} & Alauda arvensis & Skylark* $^{*}$ & \multicolumn{2}{|l|}{$\begin{array}{l}\text { W1(1), W8(1), W9(1), W10(2), } \\
\text { W16(4), W17(2), W19(1), W33(2) }\end{array}$} \\
\hline & Alectoris rufa & Red-Legged Partridge & \multicolumn{2}{|l|}{ W17(1) } \\
\hline & Perdix perdix & Grey Partridge* & \multicolumn{2}{|l|}{ W16(1) } \\
\hline & Phasianus colchicus & Pheasant & \multicolumn{2}{|l|}{ W19(1) } \\
\hline Insectivorous & Dendrocopos major & Great Spotted & \multirow{2}{*}{\multicolumn{2}{|c|}{ S5(1), S6(1) }} \\
\hline Woodland & & Woodpecker & & \\
\hline $\begin{array}{l}\text { Insectivorous } \\
\text { Woodland }\end{array}$ & Erithacus rubecula & Robin & W10(1), W22/23/24(2) & $\begin{array}{l}\mathrm{M} 1(2), \mathrm{S} 4(4), \mathrm{S} 5(4), \mathrm{D} 6(3), \mathrm{S} 6(1), \mathrm{S} 11(4), \\
\mathrm{S} 10(5), \mathrm{S} 9(3), \mathrm{S} 15(1)\end{array}$ \\
\hline \multirow[t]{4}{*}{ (Thrushes and Allies) } & Luscinia megarhynchos & Nightingale & \multicolumn{2}{|l|}{ W8(1), W22/23/24(1), W17(1) } \\
\hline & Phoenicurus phoenicurus & Redstart & & $\mathrm{S} 10(2)$ \\
\hline & Turdus merula & Blackbird & \multirow[t]{2}{*}{ W1(2), W8(1), W22/23/24 (2), W33(1) } & $\begin{array}{l}\mathrm{M} 1(3), \mathrm{S} 4(2), \mathrm{S} 5(2), \mathrm{D} 6(3), \mathrm{S} 9(2), \mathrm{S} 10(2), \\
\mathrm{S} 13(2)\end{array}$ \\
\hline & & Song Thrush* & & $S 9(1), S 10(1)$ \\
\hline
\end{tabular}




\begin{tabular}{|c|c|c|c|c|}
\hline Insectivorous & Aegithalos caudatus & Long Tailed Tit & W10(1), W22/23/24(2) & $\mathrm{S} 11(1), \mathrm{S} 13(1)$ \\
\hline \multicolumn{5}{|l|}{ Woodland } \\
\hline \multirow[t]{4}{*}{ (Paridae and Allies) } & Cyanistes caeruleus & Blue Tit & $\begin{array}{l}\text { W(3) W8(1), W9(3), W10(3), W16(1), } \\
\text { W17(1), W19(2), W22/23/24 (4), } \\
\text { W34(1), W37(2) }\end{array}$ & $\begin{array}{l}\mathrm{M} 1(2), \mathrm{S} 4(5), \mathrm{S} 5(2), \mathrm{D} 6(2), \mathrm{S} 6(3), \mathrm{S} 7(3) \\
\mathrm{S} 13(3), \mathrm{S} 9(2), \mathrm{S} 10(3), \mathrm{S} 11(5), \mathrm{S} 15(3)\end{array}$ \\
\hline & Parus major & Great Tit & $\begin{array}{l}\text { W1(2), W8(1), W9(1), W10(3), } \\
\text { W16(1),W17(1), W22/23/24(1), } \\
\text { W34(2), W37(1) }\end{array}$ & $\begin{array}{l}\mathrm{S} 4(3), \mathrm{S} 5(1), \mathrm{S} 6(1), \mathrm{S} 9(2), \mathrm{S} 10(1), \mathrm{S} 11(2), \\
\mathrm{S} 13(3), \mathrm{S} 15(2)\end{array}$ \\
\hline & Periparus ater & Coal Tit & W1(1), W10(1) W22/23/24(1) & \\
\hline & Poecile palustris & Marsh Tit* & W1(1) & M1(2) \\
\hline \multirow{4}{*}{$\begin{array}{l}\text { Insectivorous } \\
\text { Woodland (Certhioidia) }\end{array}$} & Certhia familiaris & Treecreeper & & M1(1), S15(2) \\
\hline & Sitta europaea & Nuthatch & & S5(1), D6(1), S15(2) \\
\hline & Trogloydes trogloydes & Wren & $\begin{array}{l}\text { W1(1), W8(1), W9(2), W10(4), } \\
\text { W19(2),W22/23/24(2),W34(4), }\end{array}$ & $\begin{array}{l}\text { M1(4), S4(1), S5(1), D6(3), S6(3), S7(5), } \\
\text { S9(4), S10(4), S11(4), S13(5), S15(4) }\end{array}$ \\
\hline & & & W37(4) & \\
\hline
\end{tabular}

$\begin{array}{lllll}\begin{array}{l}\text { Insectivorous } \\ \text { Woodland }\end{array} & \text { Muscicapa striata } & \text { Spotted Flycatcher* } & \begin{array}{l}\text { W10(2), W22/23/24(1), W33(1) } \\ \text { W34(1) }\end{array} & \text { D6(1), S6(1), S9(1) } \\ \text { (Warblers and Allies) } & \begin{array}{l}\text { Phylloscopus colybita/ } \\ \text { trochilus }\end{array} & \begin{array}{l}\text { Chiffchaff/Willow } \\ \text { Warbler }\end{array} & \begin{array}{l}\text { W1(1), W10(4), W19(1), } \\ \text { W22/23/24(1), W37(1) }\end{array}\end{array}$


Prunella modularis

Dunnock

Regulus regulus

Sylvia borin/atricapilla (G)

Goldcrest

Garden

Warbler/Blackcap
W10(1), W33(2), W34(1)

W33(1), W34(1)

W8(2), W9(1), W10(1), W16(1) W17(1), W22/23/24(3), W33(1),
$S 4(1), S 11(1), S 13(1), S 15(2)$

S11(1)

M1(1), D6(3), S4(1), S10(3), S11(1), S13(1)

\section{Insectivorous \\ Open Country \\ (Warblers)}

Sylvia communis

Whitethroat

Sylvia curruca

Lesser Whitethroat
W1(2), W9(2), W10(3), W16(1),

W17(1), W19(1), W22/23/24(4)

W33(4) W34(1)

W17(1), W22/23/24(4), W34(1) W37(1)

D6(2), S7(3)

Reed Nesting Warblers

$\begin{array}{lll}\begin{array}{l}\text { Acrocephalus } \\ \text { schoenobaenus }\end{array} & \text { Sedge Warbler } & \text { W9(3) } \\ \text { Acrocephalus scirpaceus } & \text { Reed Warbler } & \text { W10(1) }\end{array}$

Acrocephalus scirpaceus

W10(1)

\begin{tabular}{|c|c|c|c|c|}
\hline \multirow[t]{2}{*}{$\begin{array}{l}\text { Insectivorous open } \\
\text { country (Pipits and } \\
\text { Wagtails) }\end{array}$} & Anthus pratensis & Meadow Pipit & & M1(1), S4(1) \\
\hline & Motacilla flava & Yellow Wagtail* & W33(1) & \\
\hline \multirow{3}{*}{$\begin{array}{l}\text { Insectivorous open } \\
\text { country (swifts and } \\
\text { swallows) }\end{array}$} & Apus apus & Swift & $\begin{array}{l}\text { W10(3), W22/23/24(1), W33(1), } \\
\text { W34(1) }\end{array}$ & $S 13(1)$ \\
\hline & Delichon urbicum & House Martin & W10(1), W19(2), W33(1) & \\
\hline & Hirundo rustica & Swallow & $\begin{array}{l}\text { W16(2), W9(1), W10(3), W17(3), } \\
\text { W33(3), W34(4), W37(1) }\end{array}$ & $S 13(1)$ \\
\hline
\end{tabular}

Corvids Corvus corone Carrion Crow $\quad$ W9(1) W19(1) M1(1), S10(1), S11(1), S13(1), S15(1)




\begin{tabular}{|c|c|c|c|c|c|}
\hline & Corvus monedula & Jackdaw & W17(1), W19(1), W34(1) & S9(1), S13(2) & $\begin{array}{l}946 \\
947\end{array}$ \\
\hline & Garrulus glandarius & Jay & & $\mathrm{D} 6(1)$ & \\
\hline & Pica pica & Magpie & W10(2) & S5(1), S13(2) & 949 \\
\hline \multirow[t]{2}{*}{ Doves } & Columba palumbus & Woodpigeon & $\begin{array}{l}\text { W1(3), W8(2), W9(3), W10(2), } \\
\text { W16(1), W17(1), W19(1), } \\
\text { W22/23/24(3), W34(2) }\end{array}$ & $\begin{array}{l}\mathrm{M} 1(1), \mathrm{S} 13(4), \mathrm{S} 5(5), \mathrm{D} 6(1), \mathrm{S} 6(2), \mathrm{S} 7( \\
\mathrm{S} 9(2), \mathrm{S} 10(2), \mathrm{S} 11(2), \mathrm{S} 15(5)\end{array}$ & $\left.{ }^{2}\right)$ \\
\hline & Streptopelia decaocto & Collared Dove & W1(1) & S9(1) & 952 \\
\hline \multirow[t]{3}{*}{ Birds of Prey } & Accipiter nisus & Sparrowhawk & W19(1) & & 953 \\
\hline & Strix aluco & Tawny Owl & & $S 7(1)$ & 954 \\
\hline & Tyto alba & Barn Owl & W1(1) & & 955 \\
\hline \multirow[t]{3}{*}{ Shorebirds } & Haematopis ostralegus & Oystercatcher & & $S 13(1)$ & 956 \\
\hline & Larus melanocephalus & Black-Headed Gull & $\begin{array}{l}\text { W19(1), W22/23/24(1), W33(2), } \\
\text { W34(1) }\end{array}$ & $\mathrm{S} 13(1)$ & 957 \\
\hline & & & & & 958 \\
\hline
\end{tabular}

W $=$ Manor Farm ponds, $S=$ Stody $/$ Hunworth ponds, $M=$ Melton Constable ponds, $D=$ Daniel's ponds. ${ }^{~}$ indicates UK Biodiversity Action Plan (BAP) species

961 a Seed eaters which become insectivorous during the breeding season and when provisioning young

962 b Values inside brackets indicate frequency of visits i.e. number of surveys present out of a total of five (scores $=1-5)$.

$963 G$ Classification to genus level only. 
968 Table B.1 Observations of the activities and locations of 12 observed bird species at open, managed ponds.

\begin{tabular}{|c|c|c|c|c|c|c|c|c|c|c|c|c|}
\hline Species Name & $\begin{array}{l}\text { Hirundo } \\
\text { rustica }\end{array}$ & $\begin{array}{l}\text { Alauda } \\
\text { arvensis }\end{array}$ & $\begin{array}{l}\text { Gallinula } \\
\text { chloropus }\end{array}$ & $\begin{array}{l}\text { Anas } \\
\text { platyrhynchos }\end{array}$ & $\begin{array}{l}\text { Emberiza } \\
\text { schoeniclus }\end{array}$ & $\begin{array}{l}\text { Emberiza } \\
\text { citrinella }\end{array}$ & $\begin{array}{l}\text { Fringilla } \\
\text { coelebs }\end{array}$ & $\begin{array}{l}\text { Cyanistes } \\
\text { caeruleus }\end{array}$ & $\begin{array}{l}\text { Troglodytes } \\
\text { troglodytes }\end{array}$ & $\begin{array}{l}\text { Phylloscopus } \\
\text { collybita }\end{array}$ & $\begin{array}{l}\text { Sylvia } \\
\text { communis }\end{array}$ & $\begin{array}{l}\text { Turdus } \\
\text { merula }\end{array}$ \\
\hline Common Name & Swallow & Skylark & Moorhen & Mallard & Reed Bunting & Yellowhammer & Chaffinch & Blue Tit & Wren & Chiffchaff & Whitethroat & Blackbird \\
\hline $\begin{array}{l}\text { Foraging/ } \\
\text { hunting }\end{array}$ & $39(1)^{a}$ & 0 & 0 & 4 & 0 & 0 & 5 & 19 & 0 & 0 & $20(5)$ & $1(1)$ \\
\hline $\begin{array}{l}\text { Pair/group } \\
\text { behaviour }\end{array}$ & 35 & 9 & 8 & 16 & 4 & 2 & 29 & 36 & 0 & 0 & 16 & 0 \\
\hline $\begin{array}{l}{ }^{*} \text { Evidence of } \\
\text { provisioning } \\
\text { chicks }\end{array}$ & 2 & 0 & $2^{b}$ & $4^{b}$ & 0 & 0 & 4 & 2 & 0 & 0 & 18 & 1 \\
\hline $\begin{array}{l}\text { Sheltering/ } \\
\text { using cover }\end{array}$ & 1 & 11 & 31 & 8 & 8 & 15 & 35 & 37 & 23 & 4 & 34 & 5 \\
\hline Perching & 1 & 5 & 4 & 0 & 9 & 14 & 44 & 53 & 24 & 4 & 29 & 5 \\
\hline $\begin{array}{l}\text { Territorial } \\
\text { behaviour; singing }\end{array}$ & 2 & 16 & 0 & 0 & 2 & 18 & 21 & 28 & 19 & 4 & 12 & 2 \\
\hline Calling & 15 & 0 & 24 & 5 & 3 & 1 & 7 & 14 & 4 & 0 & 21 & 4 \\
\hline $\begin{array}{l}\text { Riparian } \\
\text { vegetation; } \\
\text { shrubs and } \\
\text { trees }\end{array}$ & 1 & 6 & 18 & 8 & 6 & 14 & 54 & 55 & 21 & 4 & 30 & 6 \\
\hline Reeds/rushes & 0 & 1 & 17 & 1 & 2 & 0 & 0 & 0 & 0 & 0 & 7 & 0 \\
\hline $\begin{array}{l}\text { Grassland } \\
\text { buffer }\end{array}$ & 0 & 8 & 0 & 0 & 5 & 3 & 2 & 3 & 3 & 0 & 9 & 0 \\
\hline Bank/pond edge & 0 & 0 & 16 & 4 & 1 & 0 & 8 & 2 & 2 & 0 & 4 & 1 \\
\hline $\begin{array}{l}\text { Swimming in } \\
\text { open water }\end{array}$ & 0 & 0 & 13 & 13 & 0 & 0 & 0 & 0 & 0 & 0 & 0 & 0 \\
\hline
\end{tabular}


a For foraging data, brackets indicate number of times individuals were observed with prey items in mouth.

97

${ }^{b}$ Confirmation of young accompanied by adults in the case of waterfowl and rallids.

974

975

976 
991 Table B.2 Observations of the activities and locations of 12 observed bird species at overgrown, terrestrialised ponds.

992

\begin{tabular}{|c|c|c|c|c|c|c|c|c|c|c|c|c|}
\hline $\begin{array}{l}\text { Species Name } \\
\text { Common Name }\end{array}$ & $\begin{array}{l}\text { Hirundo } \\
\text { rustica } \\
\text { Swallow }\end{array}$ & $\begin{array}{l}\text { Alauda } \\
\text { arvensis } \\
\text { Skylark }\end{array}$ & $\begin{array}{l}\text { Gallinula } \\
\text { chloropus } \\
\text { Moorhen }\end{array}$ & $\begin{array}{l}\text { Anas } \\
\text { platyrhyncos } \\
\text { Mallard }\end{array}$ & $\begin{array}{l}\text { Emberiza } \\
\text { schoeniclus } \\
\text { Reed } \\
\text { Bunting }\end{array}$ & Emberiza citrinella & $\begin{array}{l}\text { Fringilla } \\
\text { coelebs } \\
\text { Chaffinch }\end{array}$ & $\begin{array}{l}\text { Cyanistes } \\
\text { caeruleus } \\
\text { Blue Tit }\end{array}$ & $\begin{array}{l}\text { Trogloydes } \\
\text { trogloydes } \\
\text { Wren }\end{array}$ & $\begin{array}{l}\text { Phylloscopus } \\
\text { colybita } \\
\text { Chiffchaff }\end{array}$ & $\begin{array}{l}\text { Sylvia } \\
\text { communis } \\
\text { Whitethroat }\end{array}$ & $\begin{array}{l}\text { Turdus } \\
\text { merula } \\
\text { Blackbird }\end{array}$ \\
\hline $\begin{array}{l}\text { Foraging/ } \\
\text { hunting }\end{array}$ & $\overline{1}$ & 0 & 0 & $\overline{0}$ & 0 & 0 & 4 & $\overline{6}$ & 4 & $\overline{2}$ & 0 & $3(1)^{a}$ \\
\hline $\begin{array}{l}\text { Pair/ group } \\
\text { behaviour }\end{array}$ & 0 & 0 & 2 & 0 & 0 & 2 & 8 & 19 & 0 & 6 & 0 & 0 \\
\hline $\begin{array}{l}\text { Evidence of } \\
\text { provisioning } \\
\text { chicks }\end{array}$ & 0 & 0 & $5^{b}$ & 0 & 0 & 0 & 0 & 0 & 0 & 0 & 0 & 1 \\
\hline $\begin{array}{l}\text { Sheltering/ } \\
\text { using cover }\end{array}$ & 0 & 0 & 14 & 0 & 0 & 19 & 29 & 39 & 41 & 21 & 2 & 16 \\
\hline Perching & 1 & 0 & 0 & 0 & 0 & 19 & 40 & 52 & 31 & 24 & 5 & 18 \\
\hline $\begin{array}{l}\text { Territorial } \\
\text { behaviour; singing }\end{array}$ & 0 & 0 & 0 & 0 & 0 & 20 & 23 & 34 & 35 & 21 & 5 & 3 \\
\hline Calling & 0 & 0 & 15 & 0 & 0 & 0 & 6 & 32 & 15 & 3 & 0 & 12 \\
\hline $\begin{array}{l}\text { Riparian } \\
\text { vegetation; shrubs } \\
\text { and trees }\end{array}$ & 0 & 0 & 11 & 0 & 0 & 22 & 41 & 59 & 53 & 24 & 5 & 17 \\
\hline Reeds/rushes & 0 & 0 & 14 & 0 & 0 & 0 & 0 & 0 & 3 & 1 & 0 & 0 \\
\hline Grassland buffer & 0 & 0 & 0 & 0 & 0 & 0 & 0 & 0 & 0 & 0 & 0 & 0 \\
\hline Bank/pond edge & 0 & 0 & 13 & 0 & 0 & 0 & 0 & 1 & 17 & 4 & 1 & 5 \\
\hline $\begin{array}{l}\text { Swimming in open } \\
\text { water }\end{array}$ & 0 & 0 & 7 & 0 & 0 & 0 & 0 & 0 & 0 & 0 & 0 & 0 \\
\hline
\end{tabular}

$994{ }^{*}$ Evidence of provisioning chicks was determined by the occurrence of repeated visits to a site suspected to contain a nest or chicks by pairs of groups to the same site.

995 Includes observations of individuals bringing food items to the site and/or taking turns to forage and guard territory.

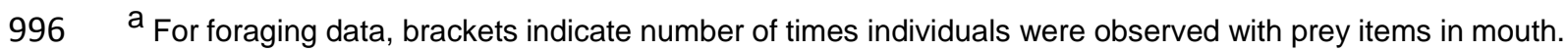

997 b Confirmation of young accompanied by adults in the case of waterfowl and rallids. 
